\title{
3. CALCAREOUS NANNOFOSSIL BIOSTRATIGRAPHY FROM LEG 101, NORTHERN BAHAMAS 1
}

\author{
David K. Watkins ${ }^{2}$ and Joost W. Verbeek ${ }^{3}$
}

\begin{abstract}
Leg 101 of the Ocean Drilling Program drilled 19 holes at 11 sites to investigate the geology of the Straits of Florida and the northern Bahamas. Drilling at Site 626 indicated that the Gulf Stream has had significant flow through the Straits of Florida for at least the last 24 million years. Winnowed, foraminiferal grainstones and packstones with sparse nannofossil assemblages and the reworking of older nannofossils suggest strong bottom-current activity throughout this interval. Drilling north of Little Bahama Bank and in Exuma Sound documents the growth of platform slopes during the late Cenozoic. Nannofossil biostratigraphy of the upper Cenozoic sediments from the Little Bahama Bank and Exuma Sound slope transects indicates relatively continuous deposition, with only short breaks in the periplatform ooze and/or calciturbidite accumulation during the late Pliocene. These unconformities may be linked to sea-level lowstands. Nannofossil assemblages are generally poorly preserved owing to accelerated diagenesis caused by high aragonite and high magnesium calcite contents of bank-derived material. High rates of influx of bank-derived materials appear to coincide with highstands of sea level.

Periplatform sediments are largely limited to the upper Cenozoic at Little Bahama Bank. Pelagic and/or hemipelagic conditions existed during the Late Cretaceous and Paleogene. A relatively complete, continuous section of Oligocene is present in the Little Bahama Bank area, although the rest of the Paleogene is thin. Paleogene material is also present in Northeast Providence Channel, although its thickness is uncertain. A thick upper Campanian chalk sequence with abundant, moderately to well-preserved nannofossils occurs in the Little Bahama Bank area. Hemipelagic nannofossil marls and marly chalks at Little Bahama Bank contain an excellent nannofossil record, which indicates a continuous lowermost to middle Cenomanian sequence overlying the upper Albian drowned platform. These hemipelagic sediments are significantly younger than the organic-rich, middle Albian limestones in Northeast Providence Channel. The latter indicate that a deep-water channel was already well established by the middle Albian.
\end{abstract}

\section{INTRODUCTION}

During February and March 1985 the scientific party of Leg 101 of the Ocean Drilling Program utilized the drilling capabilities of the deep-drilling ship JOIDES Resolution to examine several facets of the geologic history of the Bahamas. Specifically, two major scientific objectives were addressed. The first of these (the "deep" objective) was to test two apparently conflicting hypotheses on the origin of the shallow carbonate banks and intervening deep troughs that are characteristic of the modern Bahamas. The second major scientific objective of the leg was to examine the growth of carbonate banks and their response to sea-level changes (the "shallow" objective). Two transects of three sites each were planned across two different types of carbonate slopes. To address these objectives, 19 holes were drilled at 11 sites (Fig. 1). In general, drilling for the shallow objective was more successful than that for the deep objective. Only one hole $(627 \mathrm{~B})$ penetrated the target seismic horizon. Five other attempts to penetrate this horizon (at Sites $626,632,634,635$, and 636) were abandoned because of hydrocarbon shows, poor hole conditions, and/or lack of time. Drilling for the shallow objective, on the other hand, was eminently successful, with both transects yielding relatively complete records of platform evolution.

This paper is a report on shore-based studies of the nannofossils from these sediments. The purpose of this paper is twofold: (1) to report on additional, more detailed biostratigraphic work, which was impossible during the limited time available

\footnotetext{
I Austin, J. A., Schlager, W., et al., 1988. Proc. ODP, Sci. Results, 101: College Station, TX (Ocean Drilling Program).

2 Department of Geology, 330 Bessey Hall, University of Nebraska, Lincoln, NE 68588-0340.

${ }^{3}$ Rijks Geologische Dienst, Spaarne 17, Postbus 157, 2000 Ad Haarlem, Netherlands.
}

for shipboard studies; and (2) to compare these results with other information not available during the shipboard work (i.e., magnetostratigraphy, oxygen-isotope stratigraphy), which gives independent evidence for the temporal setting of Leg 101 sediments.

\section{METHODOLOGY}

The nannofossil biostratigraphy presented in this paper is largely based on examination of assemblages using the light microscope. Examination of some questionable assemblages with the scanning electron microscope (SEM) was also useful in solving taxonomic and/or biostratigraphic problems. Cenozoic nannofossil assemblages have been biostratigraphically classified using the zonation of Bukry (1973), as modified in Bukry $(1975,1981)$ and codified in Okada and Bukry (1980) and Bukry (1981). The Emiliania huxleyi Acme Zone of Gartner (1977) has also been used to subdivide the late Pleistocene material. Correlation of nannofossil zones and subzones to Cenozoic epochs and, where applicable, absolute age assignments follow Berggren et al. (1985a, 1985b). Late Cretaceous nannofossil assemblages have been placed in the biostratigraphic scheme of Perch-Nielsen (1979). The zonation of Manivit et al. (1977) has been used for the mid-Cretaceous interval. Correlation of these zones with the Cretaceous stages follows PerchNielsen (1985) unless otherwise noted in the text. Additional, or secondary, Cretaceous biostratigraphic indicators have been used where applicable and are also discussed within the text.

Nannofossil abundance and preservation varied widely in the Leg 101 material. Much of the sampled material was of poor quality, containing sparse, poorly preserved nannofossil assemblages. Apart from their value in biostratigraphically dating the sediment, these assemblages added little to our knowledge of the distribution of nannofossils in the geologic record. Because of this generally poor quality, range charts illustrating the specific distribution and abundance of taxa have been included only for stratigraphic sections where nannofossil abundance and preservation was better than the average for Leg 101 or where the age determinations were controversial. These include the entire section at Site 626 and the Cretaceous sections from Sites 627 and 635. Code letters expressing abundance and preservation of these assemblages follow conventions adopted in Watkins and Bowdler (1984). Abundances for individual nannofossil taxa are as follows: 


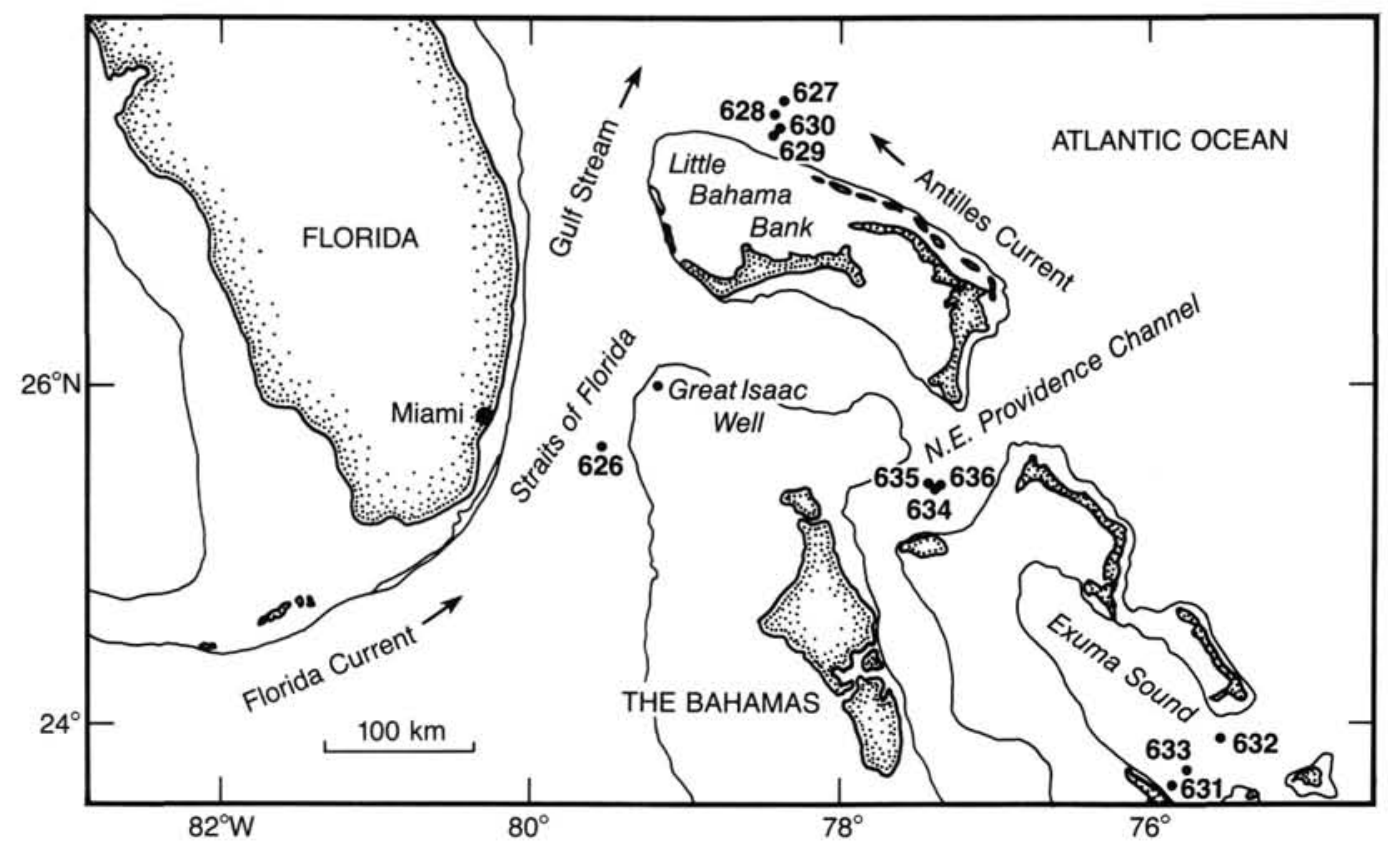

Figure 1. ODP Leg 101 sites.

$\mathrm{A}=$ abundant $(1-10$ specimens per field of view at $1500 \times)$;

$\mathrm{C}=$ common $(1$ specimen per $2-10$ fields of view at $1500 \times)$;

$\mathrm{F}=$ few $(1$ specimen per $11-100$ fields of view at $1500 \times)$;

$\mathrm{R}=$ rare (1 specimen per 101-1000 fields of view at $1500 \times)$.

An "average" state of preservation was assigned to each sample based on the following: G (good): most specimens exhibit little or no secondary alteration; $M$ (moderate): specimens exhibit the effects of secondary alteration from etching and/or overgrowth (identification of species not impaired); P (poor): specimens exhibit profound effects of secondary alteration from etching and/or overgrowth (identification of species impaired but possible).

\section{RESULTS AND DISCUSSION}

Biostratigraphic assignments for the nannofossil-bearing material recorded during Leg 101 are presented in Figure 2 (Quaternary and Neogene), Figure 3 (Paleogene), and Figure 4 (Cretaceous). A detailed discussion of these assignments with comments on preservation, nannofossil abundance, and paleoecological implications is presented below.

\section{Site 626}

Site 626 lies approximately $61 \mathrm{~km}$ east-southeast of Miami, Florida, and $28 \mathrm{~km}$ west-southwest of Bimini in the Bahamas (Fig. 1). This location is just east of the axis of the Straits of Florida and the present thalweg of the Gulf Stream. Water depth at the site is approximately $850 \mathrm{~m}$. Four holes were drilled at Site 626, of which Holes 626C and 626D are most representative of the stratigraphic section at the site. Holes $626 \mathrm{C}$ and $626 \mathrm{D}$ form a composite section that spans the upper Oligocene through Holocene (Table 1). There is a short overlap of the sections recovered in these two holes, although exact stratigraphic placement is difficult owing to poor nannofossil preservation in the lower parts of Hole $626 \mathrm{C}$. Lithologically, the section consists of three units: (1) an upper unit of foraminiferal-skeletal grainstones and packstones, (2) a middle unit of foraminiferalskeletal floatstones, and (3) a lower unit of foraminiferal-skeletal grainstones and packstones. The middle unit has been interpreted as a series of three mass-gravity-flow deposits. The upper and lower lithologic units are interpreted as contourite deposits resulting from the winnowing action of the Gulf Stream (Austin, Schlager, et al., 1986).
In general, the nannofossil assemblages exhibit moderate preservation at this site. The nannofossil assemblages are generally sparse, with relatively few taxa represented. This is probably due to the winnowing action of the Gulf Stream as it passes through the narrow Straits of Florida. Reworking of predominantly late Oligocene nannofossils into the Neogene sediments is common throughout the section. Similar reworking of larger late Oligocene nannofossils (such as Cyclicargolithus abisecta and Dictyococcites bisecta) is especially prevalent in the Quaternary. Downhole contamination of Quaternary nannofossils into the Neogene and Oligocene also occurred with some frequency. Neither the reworked forms nor the downhole contaminants are reported in the range chart (Table 1).

The surface sediments at Site 626 consist of coarse, skeletal rudstones, which are barren of nannofossils. Poor core recovery and the coarse nature of the lithology prevent biostratigraphic recognition of the latest Quaternary Emiliania huxleyi Acme Zone. Rare specimens of Emiliania huxleyi occur throughout the interval from Core 101-626C-2H through Sample 101-626C$5 \mathrm{H}-1,40-41 \mathrm{~cm}$, implying the late Quaternary Emiliania huxleyi Zone (CN15). The nannofossil assemblages are strongly dominated by specimens of small Gephyrocapsa species, however, suggesting the small Gephyrocapsa Zone of Gartner (1977), with rare specimens of Emiliania huxleyi present from downhole contamination. Small Gephyrocapsa species also dominate the nannofossil assemblages in Sections 101-626C-5H, CC and 101-626C-6H, CC. Both Emiliania huxleyi and Pseudoemiliania lacunosa are also present in these samples. These two taxa are elsewhere biostratigraphically exclusive, indicating downhole contamination of $E$. huxleyi and/or reworking of $P$. lacunosa. There is no compelling evidence to indicate whether downhole contamination or reworking (or both processes) has occurred. As a result, these samples are assigned to the composite zone CN13-15, which spans the entire Quaternary.

Sample 101-626C-7H, CC contains Reticulofenestra pseudoumbilica, Sphenolithus abies, Sphenolithus neoabies, and Discoaster asymmetricus, indicating Subzones CN10d through CN11b (early Pliocene). Poor preservation and low nannofossil abundance make it difficult to place this sample more exactly. Separation of Subzone CN10d from Zone CN11, based on the LAD (last-appearance datum) of Amaurolithus tricorniculatus 


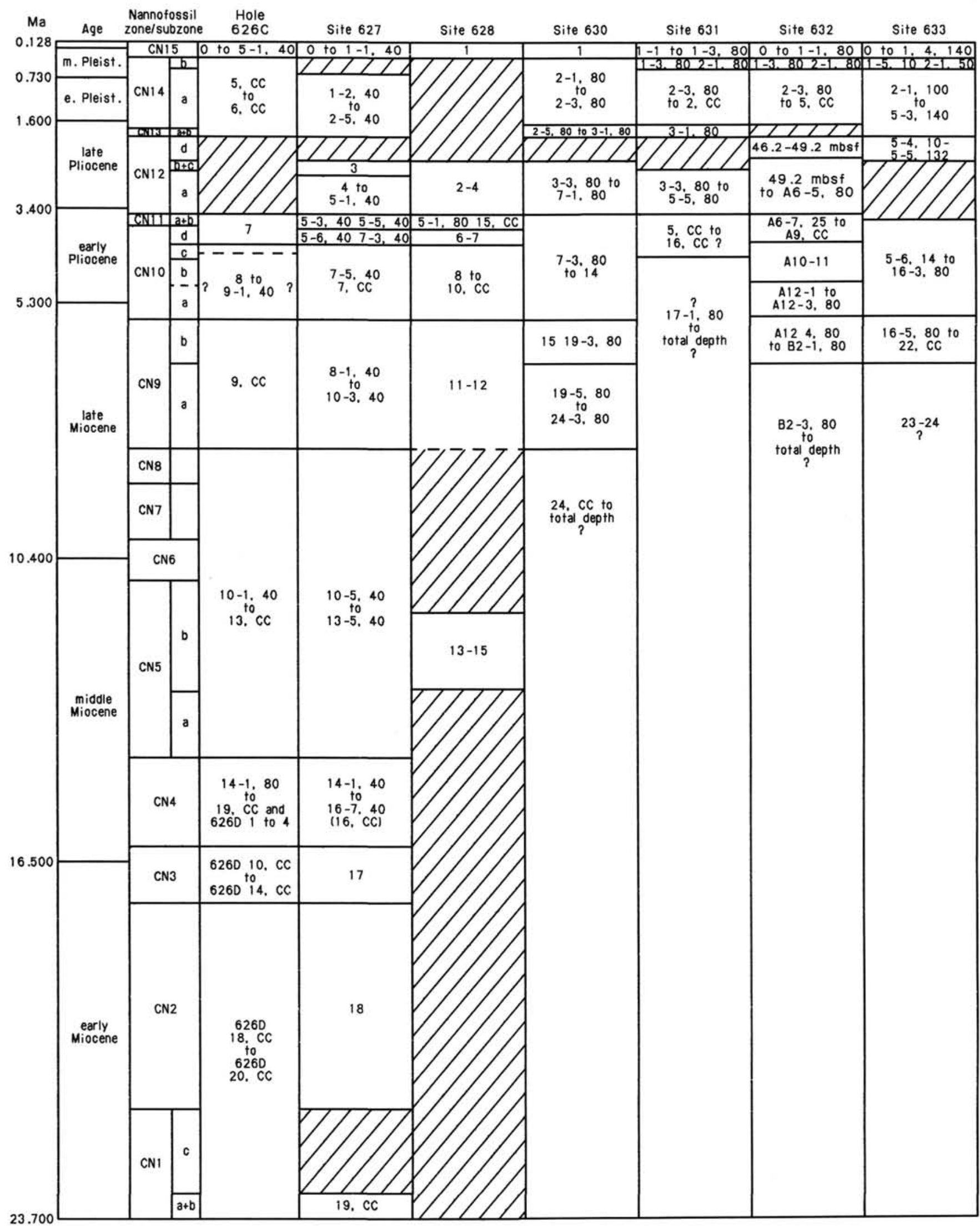

Figure 2. Summary of the nannofossil biostratigraphy for the upper Cenozoic sediments from ODP Leg 101. For sites, the following values are represented: core numbers, section numbers, and sample positions in centimeters; $\mathrm{CC}=$ core catcher. Diagonally ruled intervals denote hiatuses. 


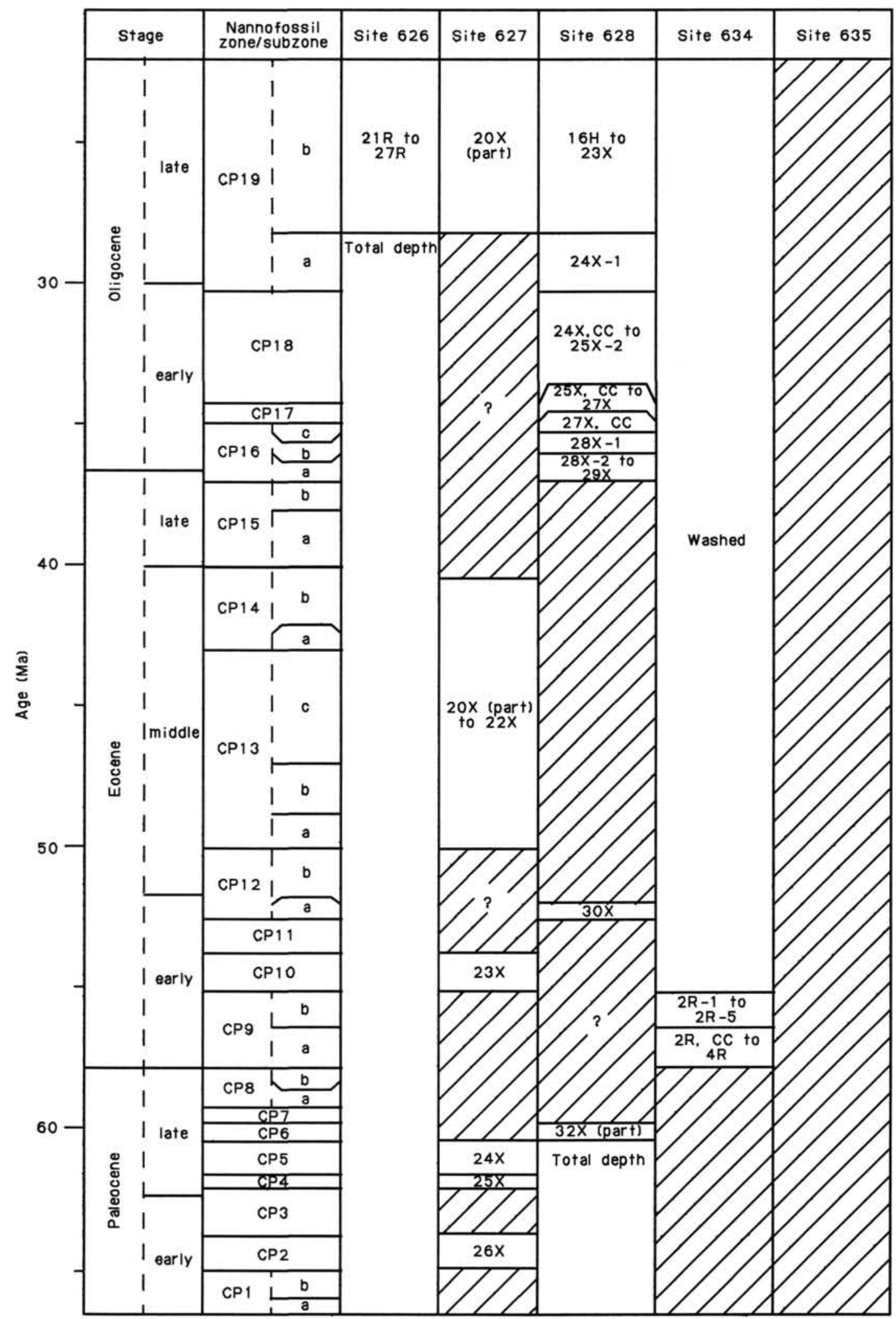

Figure 3. Summary of the nannofossil biostratigraphy for the Paleogene sediments from ODP Leg 101. Cores and sections are indicated.

(and Amaurolithus spp.), is impractical at this site. The amauroliths typically are rare in well-preserved assemblages, so that their apparent absence at this site may be an artifact of low nannofossil abundance. Separation of Subzone CN11a from Sub- zone $\mathrm{CN} 11 \mathrm{~b}$ is based on the increased abundance (acme) of Discoaster asymmetricus in Subzone CN11b. Low nannofossil abundance and poor preservation also make recognition of this acme event impossible at this site. 


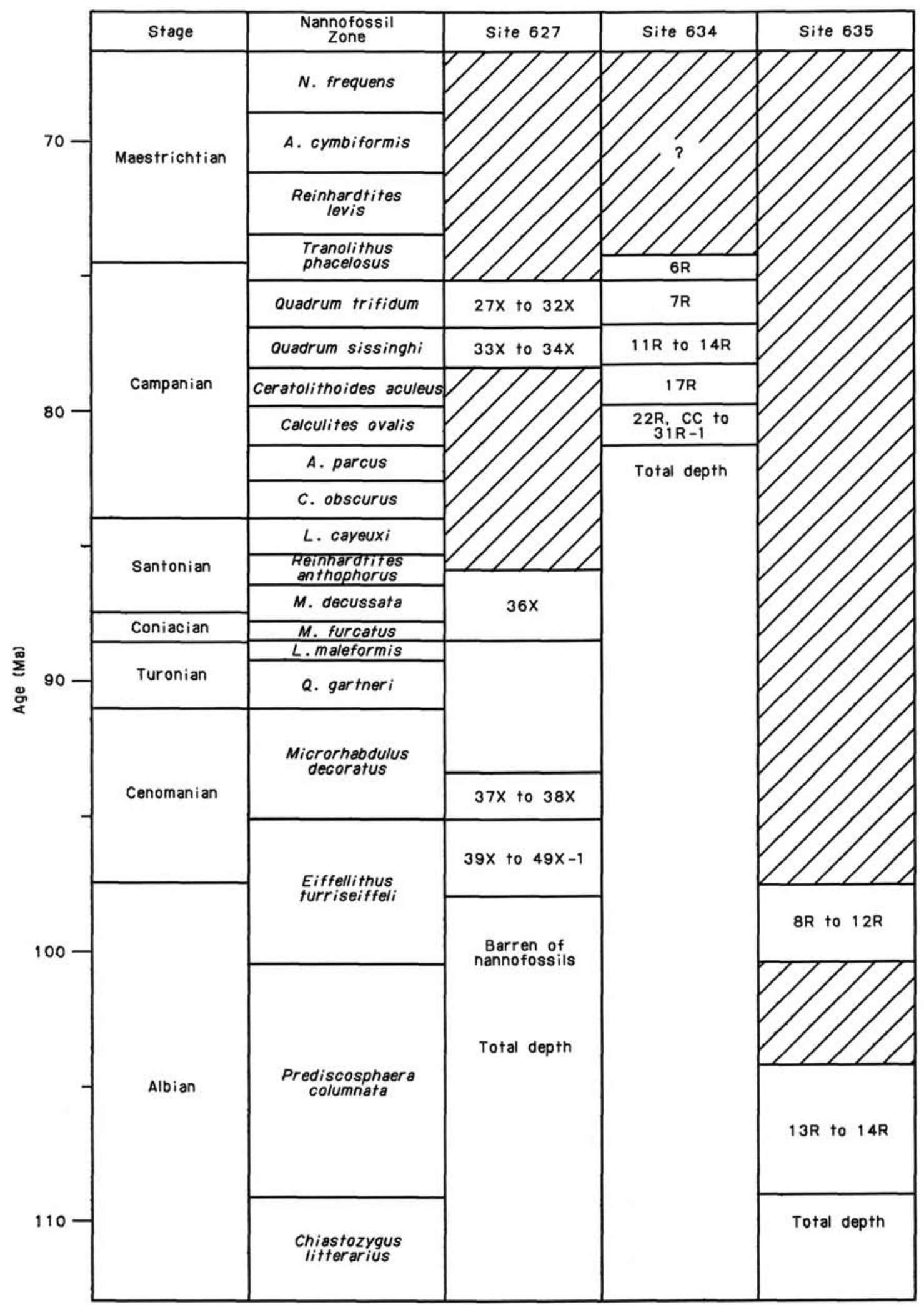

Figure 4. Summary of the nannofossil biostratigraphy for the Cretaceous sediments from ODP Leg 101. Cores and sections are indicated.

There was no sediment recovered in Core $101-626 \mathrm{C}-8 \mathrm{H}$. Sample $101-626 \mathrm{C}-9 \mathrm{H}-1,40-41 \mathrm{~cm}$, contains rare, poorly preserved nannofossils that are not age-diagnostic. Sample 101-626C$9 \mathrm{H}, \mathrm{CC}$ contains a sparse, poorly preserved assemblage that in- cludes rare specimens of Discoaster quinqueramus and Discoaster berggreni, indicating nannofossil Zone CN9 (late Miocene). Subzone assignment for this sample was impossible owing to poor preservation and low abundance. 
Table 1. Nannofossil occurrences in Holes 626C and 626D.

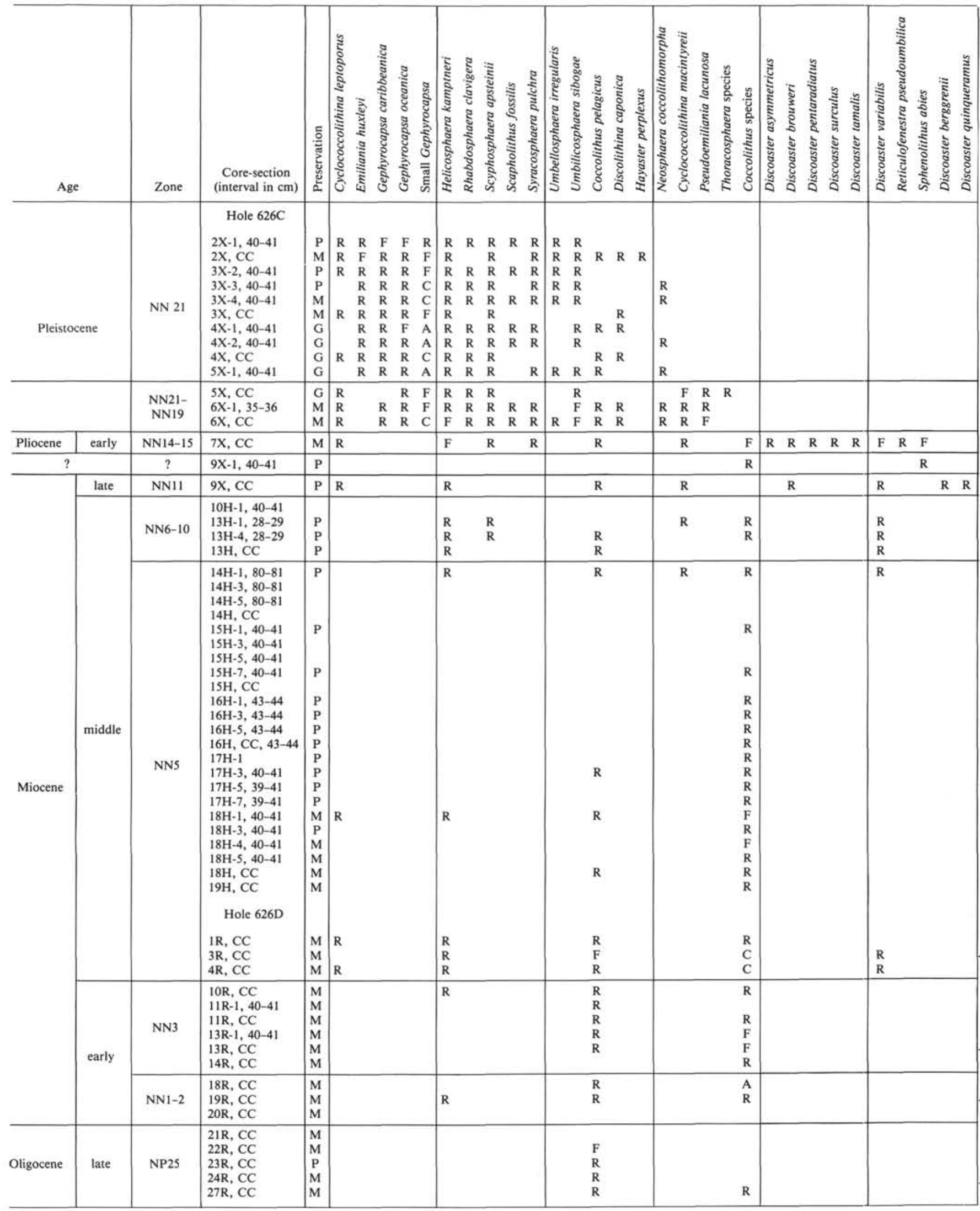

Note: Preservation: $\mathrm{P}=$ poor, $\mathrm{G}=$ good, $\mathrm{M}=$ moderate. Occurrence: $\mathrm{R}=$ rare, $\mathrm{F}=$ few, $\mathrm{C}=$ common, $\mathrm{A}=$ abundant. 
Table 1 (continued).

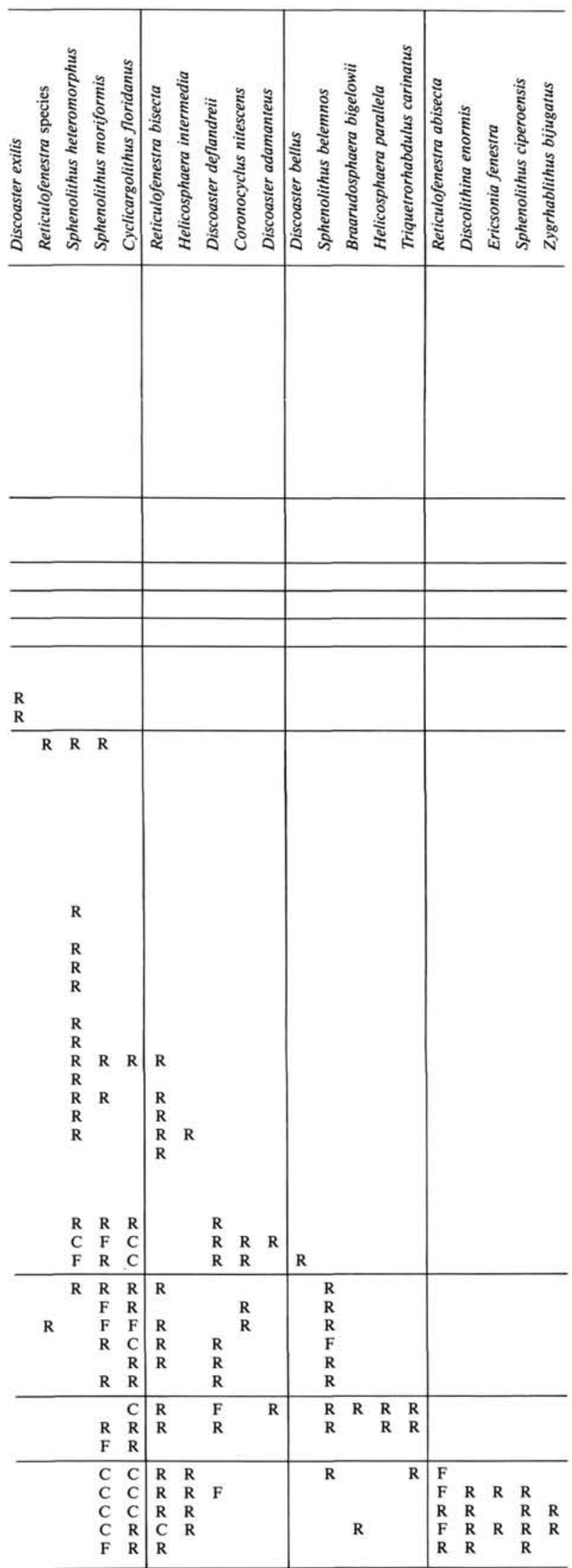

The interval from Sample 101-626C-10H-1, 40-41 cm, through $101-626 \mathrm{C}-13 \mathrm{H}, \mathrm{CC}$ contains rare, poorly preserved nannofossil assemblages that are not, in themselves, age-diagnostic. This interval is intercalated between the upper Miocene (CN9) Section 101-626C-9H, CC and the underlying middle Miocene (CN4) Sample 101-626C-14H-1, 80-81 cm. As a result, the interval is assigned to the composite zone CN4-9, which correlates to part of the middle to late Miocene. Rare specimens of Discoaster exilis in samples from Core $101-626 \mathrm{C}-13 \mathrm{H}$ corroborate this tentative assignment. Planktonic-foraminiferal evidence indicates a middle Miocene age for most of this interval (Austin, Schlager, et al., 1986).

The rare occurrence of Sphenolithus heteromorphus in Sample 101-626C-14H-1, 80-81 cm, and in the interval from Sample $101-626 \mathrm{C}-16 \mathrm{H}-1,43-44 \mathrm{~cm}$, through 101-626C-19H, CC implies nannofossil Zones CN3-4. The presence or absence of $\mathrm{He}$ licosphaera ampliaperta cannot be confidently ascertained from the sparse, poorly preserved assemblages. Indeed, samples in the interval from Sample 101-626C-14H-3, 80-81 cm, through Section 101-626C-15H, CC are essentially barren of nannofossils. Nannofossil preservation improves slightly near the base of Hole 626C (Sample 101-626C-18H-1, 40-41 cm, through Section 101-626C-19H, CC). The absence of Helicosphaera ampliaperta in this basal interval may be of biostratigraphic significance (indicating Zone CN4), although the confidence of this conclusion is rather low. Planktonic foraminifers from this interval exhibit much better preservation. These assemblages indicate a somewhat different biostratigraphic succession, with the interval from Core 101-626C-14H through 101-626C-18H assigned to the middle Miocene Globorotalia fohsi fohsi Zone (A. J. Melillo, pers. comm., 1986). Bolli et al. $(1985$, p. 6) correlate the $G$. fohsi fohsi Zone with nannofossil Subzone CN5a (in part). This correlation indicates that the rare specimens of Sphenolithus heteromorphus in Cores 101-636C-14H through 101-636C-18H are reworked. Planktonic-foraminiferal evidence corroborates the assignment of Core $101-636 \mathrm{C}-19 \mathrm{H}$ to the early middle Miocene nannofossil Zone CN4.

Core recovery in the upper part of Hole $626 \mathrm{D}$ was poor, with little usable material recovered from the first nine cores. Small sediment samples from core catchers in Cores 101-626D-1R, 101-626D-3R, and 101-626D-4R yielded sparse, moderately preserved nannofossil assemblages containing Sphenolithus heteromorphus without Helicosphaera ampliaperta. This suggests assignment to nannofossil Zone CN4, which correlates to the early middle Miocene. This age assignment is corroborated by the somewhat better preserved, more abundant planktonic-foraminiferal assemblages (Austin, Schlager, et al., 1986). Cores 101-626D-5R through 101-626D-9R either had no recovery or recovered only small, well-lithified pieces of foraminiferal grainstone/packstone that were barren of nannofossils.

Samples from Cores 101-626D-10R through 101-626D-14R contained moderately preserved nannofossil assemblages that included Sphenolithus belemnos without Triquetrorhabdulus carinatus. These assemblages indicate nannofossil Zone CN2, which correlates to the latest part of the early Miocene. Trace recovery in Cores 101-626D-15R, 101-626D-16R, and 101-626D-17R yielded no nannofossils. Core catchers from Cores 101-626D-18R, 101626D-19R, and 101-626D-20R contained nannofossil assemblages dominated by Sphenolithus moriformis and Cyclicargolithus floridanus. The presence of Triquetrorhabdulus carinatus without Sphenolithus belemnos, Dictyococcites bisectus, Zygrhablithus bijugatus, or Sphenolithus ciperoensis indicates nannofossil Zone CN1 (earliest Miocene). Subdivision of this zone is impossible owing to the sparse nature of the nannofossil assemblages.

The interval from Section 101-626D-21R, CC through Section 101-626D-27R, CC (total depth) contains moderately pre- 
served nannofossil assemblages that are relatively richer in species than the overlying section. Unfortunately, sediment recovery was poor, and only five samples containing nannofossils were available from this interval, all of which were from corecatcher samples (in Cores 101-626D-21R through 101-626D-24R and Core 101-626D-27R). These assemblages include Cyclicargolithus abisecta, Dictyococcites bisecta, Sphenolithus ciperoensis, Pontosphaera enormis, and Zygrhablithus bijugatus but lack Sphenolithus distentus. This assemblage indicates the latest Oligocene nannofossil Subzone CP19b. Core 101-626D-28R contained no sediment.

\section{Site 627}

Site 627 was the first of three successful sites drilled as part of the Little Bahama Bank slope transect. Drilling at this site addressed two important objectives: examination of the Cenozoic development of an open-ocean carbonate slope and penetration of the drowned Cretaceous carbonate platform sequence underlying the southern Blake Plateau. The abortive Hole 627A recovered only one core and is not discussed below. Hole 627B penetrated approximately $536 \mathrm{~m}$ of sediment before bottoming in Albian carbonate-platform sediments. Water depth at the site is approximately $1025 \mathrm{~m}$. The drilled stratigraphic section consists of six distinct lithologic units separated by unconformities of varying magnitude (Austin, Schlager, et al., 1986).

The interpretation of the Cenozoic calcareous nannofossils from Units I and II was severely hindered by consistent downhole contamination. This downhole contamination took two forms: large-scale infiltration of Quaternary material throughout the section and more subtle downhole contamination of middle and upper Miocene nannofossils into the lower Miocene and Paleogene sections. Reworking of Oligocene nannofossils into the Neogene section was also a frequent phenomenon. In general, the Cenozoic nannofossil assemblages from Hole 627B are poorly preserved owing to overgrowth with secondary calcite. As a result of this diagenesis, more than $25 \%$ of the nannofossils could not be determined to the species level.

Emiliania huxleyi is present as rare specimens in Sample 101$627 \mathrm{~B}-1 \mathrm{H}-1,40-41 \mathrm{~cm}$, indicating nannofossil Zone CN15 (late Quaternary). The relative rarity of $E$. huxleyi in this sample indicates that the uppermost Quaternary sediments of the Emiliania huxleyi Acme Zone of Gartner (1977) are either absent or less than $40 \mathrm{~cm}$ thick. Nannofossil Subzone CN14b was not recognized in this hole. It is possible, however, that it has been masked by reworking of Pseudoemiliania lacunosa from underlying sediments. The interval from Sample 101-627B-1H-2, 40$41 \mathrm{~cm}$, through Section 101-627B-2H, CC contains Gephyrocapsa oceanica, Gephyrocapsa caribbeanica, and Pseudoemiliania lacunosa without any discoasters, indicating nannofossil Subzone CN14a (middle Quaternary).

Samples from Core 101-627B-3H contained Discoaster brouweri and Discoaster pentaradiatus without Discoaster surculus, indicating nannofossil Subzone $\mathrm{CN}_{12} \mathrm{c}$ (late Pliocene). Specimens of Coccolithus spp. become common in this subzone and remain common to abundant throughout the rest of the Cenozoic interval. Owing to less than adequate preservation in Hole $627 \mathrm{~B}$, species of the genus Coccolithus were not differentiated unless they are distinctive under the light microscope. Discoaster surculus, Discoaster variabilis, and Discoaster tamalis occur without Reticulofenestra pseudoumbilica or Sphenolithus spp. in the interval from Samples 101-627B-4H-1, 40-41 cm, through 101-627B-5H-1, 40-41 cm. This is indicative of nannofossil Subzone $\mathrm{CN} 12 \mathrm{a}$ (late Pliocene). This interval contains a remarkably diverse assemblage of the genus Scyphosphaera, the significance of which is uncertain.

The Reticulofenestra pseudoumbilica Zone (CN11, late early Pliocene) is rather thin, occupying only the interval from Samples 101-627B-5H-3, 40-41 cm, through 101-627B-5H-5, 40-
$41 \mathrm{~cm}$. This is unfortunate, as this sediment contains the best nannofossil preservation of all the Cenozoic zones represented at this site. Below this well-preserved zone the interval from Samples 101-627B-5H-6, 40-41 cm, through 101-627B-7H-1, $40-41 \mathrm{~cm}$, contains nannofossil assemblages that include Discoaster asymmetricus and Amaurolithus tricorniculatus. This association indicates the Amaurolithus delicatus Subzone (CN10d), which correlates to part of the middle early Pliocene. Bukry (1981) notes that the overlap of $D$. asymmetricus and $A$. tricorniculatus (which defines Subzone CN10d) is either very brief or nonexistent in various sites in the Atlantic and Pacific, although this problem is not apparent at Site 627. The presence of Triquetrorhabdulus rugosus without Discoaster quinqueramus or Discoaster berggreni in Samples 101-627B-7H-3, 40-41 cm, and 101-627B-7H-5, 40-41 cm, indicates the T. rugosus Subzone (CN10a), which is correlative to the earliest Pliocene and latest Miocene (Berggren et al., 1985b). The rarity of $T$. rugosus in this interval suggests that it may be reworked from underlying Miocene sediments, so that this interval may be slightly younger.

Samples in the interval from Samples 101-627B-8H-1, 40$41 \mathrm{~cm}$, through 101-627B-10H-3, 40-41 cm, include the species Discoaster quinqueramus and Discoaster berggreni. These taxa mark the D. quinqueramus Zone (CN9), which correlates to part of the late Miocene. Nannofossil Zone CN9 is divided into two subzones, based on the FAD (first-appearance datum) of Amaurolithus primus within the zone. Preservation in this interval, however, is generally poor. As a result, division of this zone into subzones cannot be reliably accomplished. Preservation deteriorates in the underlying interval (Sample 101-627B-10H-5, $40-41 \mathrm{~cm}$, through Core 101-627B-13H), so exact zonal determination is difficult. Discoaster quinqueramus apparently is absent from this interval, suggesting that it is older than nannofossil Zone CN9. The sample immediately underlying this interval (Sample 101-627B-14H-1, 40-41 cm) contains an assemblage indicative of Zone CN4. Based on this stratigraphic relationship, the interval in question (Sample 101-627B-10H-5, 40-41 cm, through Core 101-627B-13H) is assigned to a combined zone CN4-8, which correlates to the middle Miocene through the early late Miocene. Planktonic-foraminiferal evidence indicates the younger part of this age assignment, roughly correlating to CN6-8 (A. J. Melillo, pers. comm., 1986).

Cores 101-627B-14H through 101-627B-16H contain nannofossil assemblages that include Sphenolithus heteromorphus and Discoaster exilis without Helicosphaera ampliaperta, indicating the Sphenolithus heteromorphus Zone (CN4). This zone correlates to the early middle Miocene (Berggren et al., 1985b). Discoaster variabilis becomes frequent to common in this zone, although this may be an artifact of the strong overgrowth typical of this section of Hole 627B. In Core 101-627B-17H, Helicosphaera ampliaperta joins Sphenolithus heteromorphus as a part of the assemblage, indicating nannofossil Zone CN3. Correlation of this zone by Berggren et al. (1985b) indicates that it straddles the early Miocene-middle Miocene boundary. The nannofossil assemblage in Core $101-627 \mathrm{~B}-17 \mathrm{H}$ is rather well preserved and rich. Much of this richness, however, is probably the result of reworking of upper Oligocene nannofossils into the assemblage. Numerous specimens of Dictyococcites bisecta and Cyclicargolithus floridanus imply that many of the other, longer ranging taxa in the samples are reworked Oligocene fossils. Because it is virtually impossible to separate the Oligocene specimens of some of these long-ranging taxa from co-specific Miocene specimens, their abundances probably are not representative of the true abundances of these nannoplankton in the Miocene surface waters.

Only core-catcher samples were available from Cores 101627B-18X and 101-627B-19X. These contained well-preserved nannofossil assemblages with age-diagnostic taxa. Sphenolithus 
belemnos is present in Section 101-627B-18X, CC, indicating Zone CN2 (early Miocene). Section 101-627B-19X, CC contains a somewhat different assemblage, including Triquetrorhabdulus carinatus as well as $S$. belemnos. This implies a mixed assemblage of early and earliest middle Miocene taxa. Radiolarians and planktonic foraminifers indicate an earliest Miocene age for this sample (Austin, Schlager, et al., 1986), suggesting downhole contamination of middle Miocene nannofossils.

Samples from Cores 101-627B-20X through 101-627B-22X contain nannofossil assemblages that include Helicosphaera recta, Reticulofenestra abisecta, Zygrhablithus bijugatus, and Sphenolithus ciperoensis but lack Sphenolithus distentus. These nannofossils indicate a latest Oligocene age (CP19b) for this interval. However, isolated pieces of chert and thin, clay-rich layers in this interval indicate a different age. Planktonic foraminifers from these lithologies in Cores 101-627B-20X through 101-627B-22X and radiolarians from a chert pebble in Core 101-627B-21X suggest that the interval is middle Eocene (Austin, Schlager, et al., 1986). This in turn suggests that the late Oligocene nannofossil assemblages from the base of Core 101627B-20X and from Cores 101-627B-21X through 101-627B-22X are downhole contaminants derived from a thin nannofossil chalk layer of late Oligocene age near the top of Core 101-627B-20X.

Planktonic-foraminiferal and calcareous-nannofossil biostratigraphy is once again in agreement in Core 101-627B-23X, where both microfossil groups indicate an early Eocene age. Nannofossil assemblages include Discoaster lodoensis, Coccolithus crassus, and Tribrachiatus orthostylus, indicating nannofossil Zone CN10. Downhole contamination by Miocene and Quaternary sediment is very much in evidence, although the moderately preserved, in-situ Eocene material is still abundant.

Cores 101-627B-24X through 101-627B-26X contain abundant, moderately to well-preserved Paleocene nannofossil assemblages. Core recovery was poor in this interval, so all nannofossil information is based on core-catcher samples. Section 101627B-24X, CC contains Heliolithus kleinpelli and Heliolithus riedeli without any discoasters, indicating nannofossil Zone CP5 (late Paleocene). Section 101-627B-25X, CC contains Fasciculithus tympaniformis and Ellipsolithus macellus without Heliolithus kleinpelli, indicating the lower upper Paleocene Zone CP4. Section 101-627B-26X, CC contains Chiasmolithus danicus without $F$. tympaniformis or E. macellus, indicating lower Paleocene Zone CP2. Braarudosphaera spp. are relatively common in this sample, and to a lesser degree, in the other Paleocene samples.

The Cretaceous sediments drilled at Site 627 include pelagic (Units III and IV), hemipelagic (Unit V), and shallow-water platform carbonates and evaporites (Unit VI). Nannofossil assemblages are present in Units III and V. In general, these nannofossils are quite diverse, with a total of 92 taxa identified from the Cretaceous section (Table 2). Preservation is moderate to good, with overgrowth of secondary calcite being the major diagenetic alteration (Plate 3, Figs. 1 and 2).

Nannofossil assemblages from Cores 101-627B-27X through 101-627B-32 are diverse but rather moderately preserved. The presence of Quadrum trifidum, Quadrum sissinghi, Tranolithus phacelosus, Ceratolithoides aculeus, and Eiffellithus eximius indicates the $Q$. trifidum Zone (latest Campanian). This zone is divided into informal subzones based on the FAD of Reinhardtites levis (Sissingh, 1977). However, this determination was not possible from the material from Site 627 owing to two factors: paleobiogeography and preservation. Perch-Nielsen (1985) noted that the subdivision based on the FAD of $R$. levis is most useful in higher latitudes, where species of Reinhardtites are more common. Furthermore, most of the Site 627 specimens of Reinhardtites suffer so much from overgrowth in the central area that differentiation of $R$. levis from $R$. anthophorus is difficult.
The assemblages in cores 101-627B-33X and 101-627B-34X are similar to the overlying Campanian ones, with the exception that Quadrum trifidum is not present. This association indicates the Quadrum sissinghi Zone (late Campanian).

Nannofossil assemblages of late Cenomanian through early Campanian age are not present in Hole $627 \mathrm{~B}$, although planktonic foraminifers indicate the presence of rocks of Coniacian to early Santonian age in Core 101-627B-36X (Austin, Schlager, et al., 1986).

Unit V (Cores 101-627B-37X through 101-627B-49X) consists of a sequence of lower to middle Cenomanian marly oozes, chalks, and limestones. Samples from Cores 101-627B-37X and 101-627B-38X contain moderate to poorly preserved nannofossil assemblages (Plate 3, Figs. 3 and 4) that include well-developed forms of Eiffellithus turriseiffeli, relatively large specimens of Prediscosphaera columnata (s.1.), Lithraphidites acutus, and Lithraphidites alatus without Microrhabdulus decoratus or common Gartnerago obliquum. In tropical localities, this assemblage is characteristic of the Lithraphidites acutus Zone of Manivit et al. (1977). This zone roughly correlates to the Microrhabdulus decoratus Zone of Sissingh (1977), as the FAD of Lithraphidites acutus is approximately equal to the FAD of Microrhabdulus decoratus (Perch-Nielsen, 1985). The presence of Microstaurus chiastius in Sample 101-627B-38X-5, 40-41 cm, indicates that at least the lower part of this interval is in the lower part of the $M$. decoratus Zone. This interval correlates to the middle Cenomanian.

Lithraphidites acutus is not present in the underlying part of Unit V (Cores 101-627B-39X through 101-627B-49X), although Eiffellithus turriseiffeli persists throughout. Lithraphidites alatus is sporadically present in this interval as well. Hayesites albiensis was not recognized anywhere within Unit V. This association indicates that Cores 101-627B-39X through 101-627B-49X lie within the Prediscosphaera spinosa Subzone of the Eiffellithus turriseiffeli Zone, which correlates to the late Albian through early Cenomanian. Additional biostratigraphic information allows a more precise age determination for this interval. Corollithion kennedyi occurs sporadically from Sample 101627B-39X-1, 40-41 cm, through Sample 101-627B-47X-1, 40$41 \mathrm{~cm}$. Crux (1982) notes that $C$. kennedyi first appears in the Mantelliceras mantelli Ammonite Zone of southeast England. This zone correlates with the early Cenomanian (van Hinte, 1976). Perch-Nielsen (1985) also correlates the FAD of C. kennedyi within the early Cenomanian. The LAD of Braarudosphaera africana apparently occurs at or slightly above Sample $101-627 \mathrm{~B}-46 \mathrm{X}-3,40-41 \mathrm{~cm}$. This species is known to have its LAD in rocks that correlate with the early Cenomanian, although it may persist as high as the middle Cenomanian in some areas (Perch-Nielsen, 1985). The lack of relatively smaller specimens of $P$. columnata, which dominate the prediscosphaerids from the late Albian, also suggests an early Cenomanian age for the base of Unit V. Thus, several lines of biostratigraphic evidence indicate that the base of Unit V is close to, but still above, the Albian/Cenomanian boundary.

\section{Site 628}

Site 628 was the second of three sites drilled as part of the Little Bahama Bank slope transect. The site lies at the toe-ofslope of the northern Little Bahama Bank slope, in approximately $966 \mathrm{~m}$ of water. Drilling at the site penetrated approximately $298 \mathrm{~m}$ of the sedimentary record, which spans the upper Paleocene to the Holocene. Three major lithostratigraphic units have been designated for the drilled section (Austin, Schlager, et al., 1986).

Confident assignment of nannofossil zones and subzones to the material in Unit I was dependent largely on the lithologic nature of the sediment recovered. The foraminiferal packstone- 
Table 2. Nannofossil occurrences in the Cretaceous of Hole 627B.

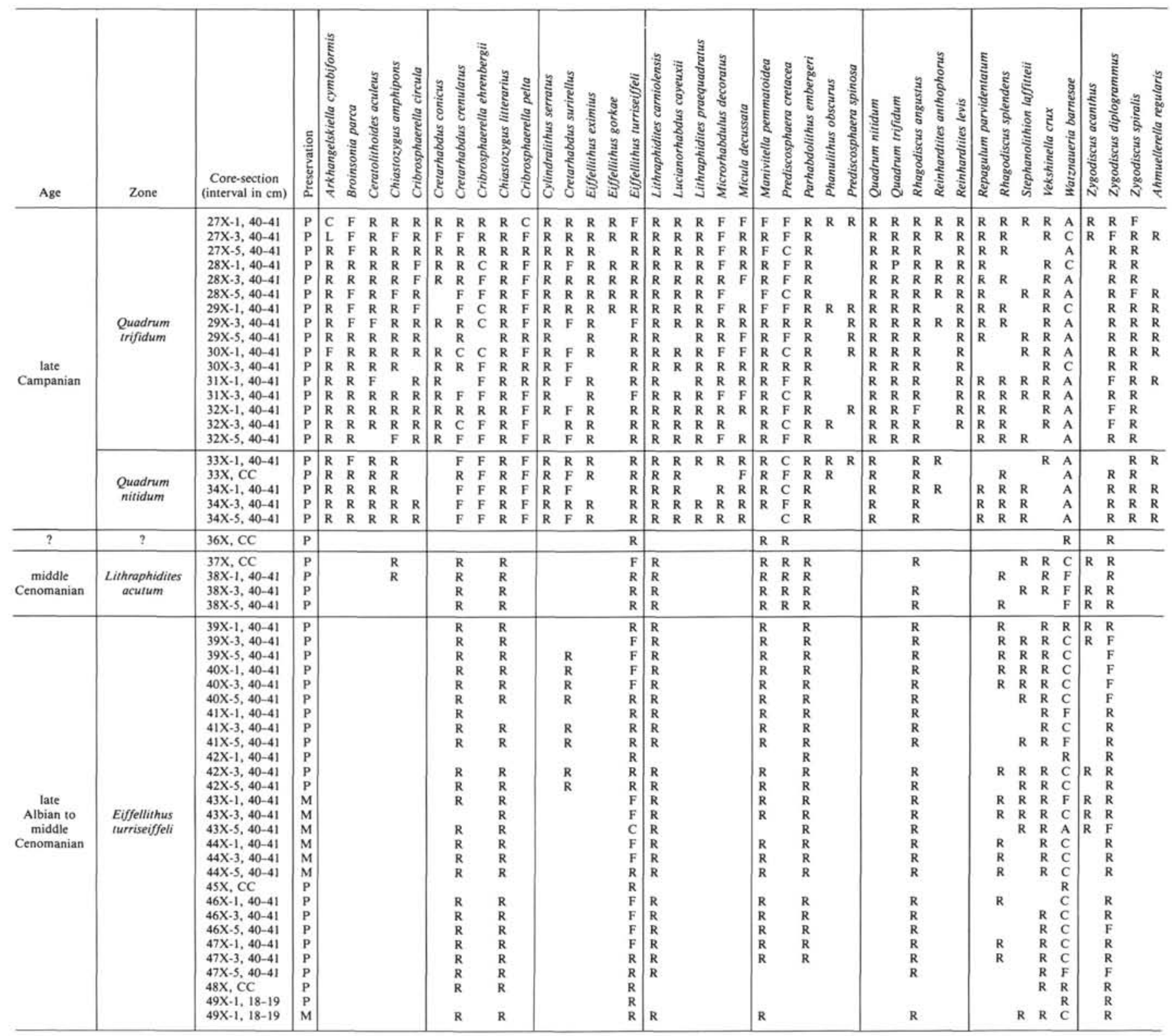

Note: Preservation: $\mathbf{P}=$ poor, $\mathrm{G}=$ good, $\mathrm{M}=$ moderate. Occurrence: $\mathbf{R}=$ rare, $\mathrm{F}=$ few, $\mathrm{C}=$ common, $\mathbf{A}=$ abundant.

grainstone intervals contained rare, poorly preserved nannofossil assemblages that commonly were age-diagnostic only at the zonal (not subzonal) level. Planktonic foraminifers generally yielded more precise, reliable age determinations from this lithotype. Nannofossil preservation and abundance within the periplatform oozes generally were better, although subzonal assignments still were not always possible.

Core 101-628A-1H consists primarily of a debris-flow deposit. The hard, gravel-sized clasts are too well lithified to yield nannofossils. The softer matrix material contains assemblages that include Emiliania huxleyi, Gephyrocapsa caribbeanica, and Gephyrocapsa oceanica. The assemblages are dominated by the gephyrocapsids, especially $G$. caribbeanica. These nannofossils indicate the lower portion of the $E$. huxleyi Zone (CN15), below the E. huxleyi Acme Zone of Gartner (1977). This correlates to the late middle to late Pleistocene. The dominance of the assem- blages by the gephyrocapsids indicates an age of between 0.275 and $0.085 \mathrm{Ma}$ for the matrix of the debris flow.

The interval from Cores 101-628A-2H through 101-628A-4H consists predominantly of foraminiferal packstones and grainstones. Very sparse, poorly preserved nannofossil assemblages from this interval suggest nannofossil Subzones CN12a-c (late Pliocene). Discoaster brouweri, Discoaster triradiatus, Discoaster pentaradiatus, Discoaster surculus, and Discoaster sp. cf. $D$. tamalis occur as rare specimens in this interval. This tentative age designation is partially corroborated by planktonic foraminifers, which indicate an assignment of cores 101-628A-2H and 101-628A-3H to the late Pliocene. Planktonic foraminifers in Section 101-628A-4H, CC, however, yield an early Pliocene age, based on assemblages that contain Globorotalia margaritae. Correlative nannofossil assemblages should contain species such as Reticulofenestra pseudoumbilica and Sphenolithus abies. Some 


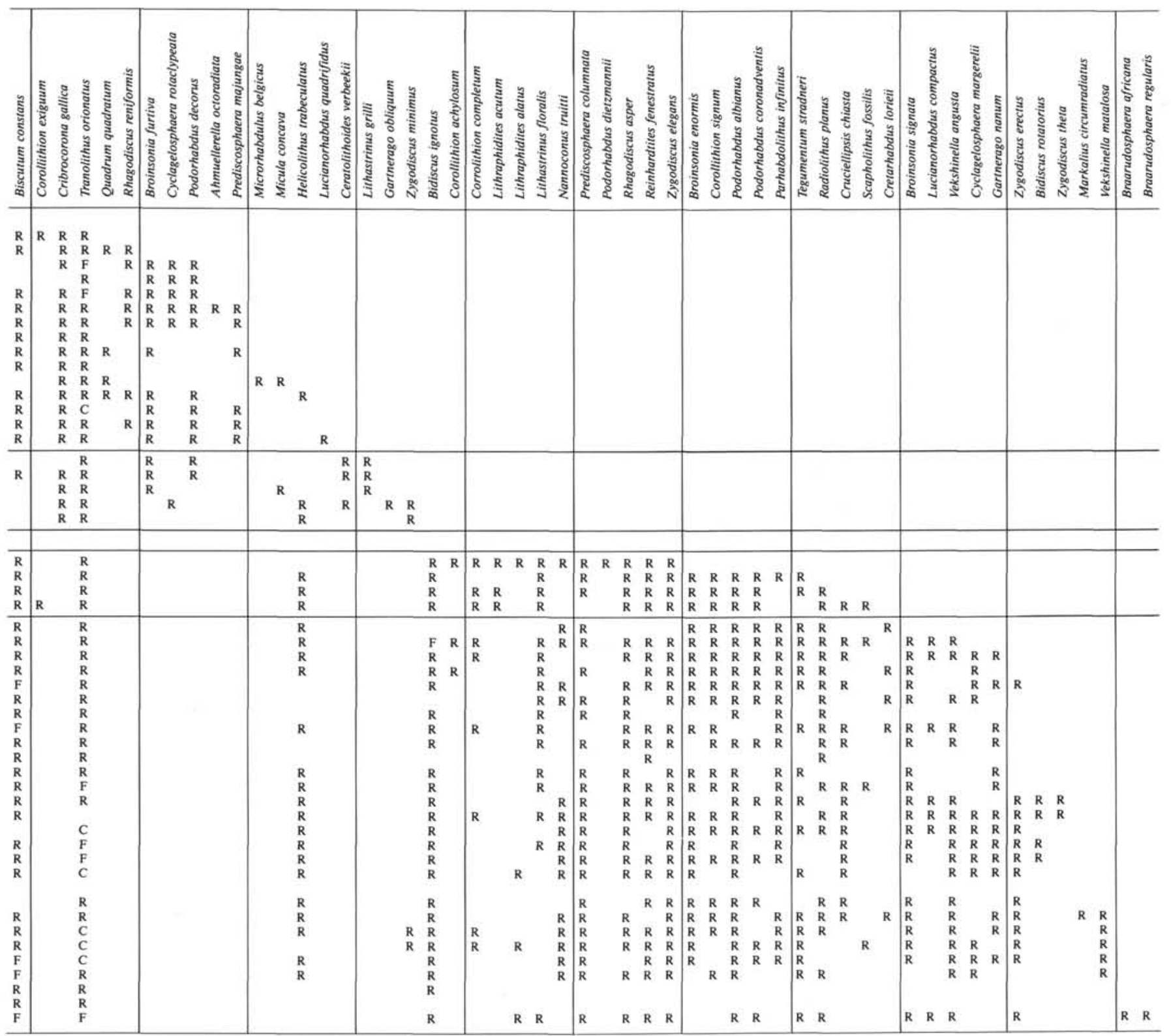

small specimens similar to (but not believed to be conspecific with) $R$. pseudoumbilica were observed throughout the interval, but no sphenoliths were seen. Because of the poor quality of the nannofossils from this interval, the planktonic-foraminiferal results probably are more valid.

Reticulofenestra pseudoumbilica, Sphenolithus abies, Sphenolithus neoabies, Discoaster asymmetricus, and Discoaster tamalis are present in Samples 101-628A-5H-1, 80-81 cm, through 101-628A-5H, CC. This association, and the lack of Amaurolithus primus and Amaurolithus tricorniculatus, is indicative of nannofossil Zone CN11, which correlates to the late early Pliocene. The amauroliths appear, and $D$. tamalis is not present, in the underlying interval (Cores 101-628A-6H to 101-628A-10H), indicating nannofossil Zone $\mathrm{CN} 10$ (latest Miocene to early Pliocene). Subdivision of this zone into two subzonal units is possible through the use of the FAD of Discoaster asymmetricus.
This species occurs in samples from Cores 101-628A-6H and 101-628A-7H, indicating Subzone CN10d (early Pliocene). Rare, questionable specimens of $D$. asymmetricus were reported in the course of shipboard work, but these could not be corroborated by more intensive shore-based studies. In addition, preservation and abundance are too poor to use other subzonal indicators within this zone. Thus, Cores 101-628A-8H through 101$628 \mathrm{~A}-10 \mathrm{H}$ are assigned to the composite subzones $\mathrm{CN} 10 \mathrm{a}-\mathrm{c}$ (latest Miocene through earliest Pliocene).

Poorly preserved but moderately abundant nannofossils from packstones in Cores 101-628A-11 H and 101-628A-12H contain Discoaster quinqueramus and Discoaster berggreni. These species indicate nannofossil Zone CN9 (late Miocene). No amauroliths were observed in these assemblages. It could not be reliably ascertained from nannofossil evidence whether this was the result of poor preservation or biostratigraphic exclusion. Plank- 
tonic-foraminiferal evidence, however, suggests that this interval was deposited prior to the evolution of the amauroliths. Assuming this to be true, this interval falls entirely within nannofossil Subzone CN9a. Planktonic-foraminiferal evidence also suggests that a significant unconformity separates these upper Miocene sediments from the underlying middle Miocene in Cores 101$628 \mathrm{~A}-13 \mathrm{H}$ through $101-628 \mathrm{~A}-15 \mathrm{H}$. The calcareous-nannofossil assemblages in this latter interval are sparse and poorly preserved. In most of the samples, Oligocene species such as Dictyococcites bisectus and Reticulofenestra abisecta dominate the assemblages. In some samples, such as 101-628A-14H-1, 80-81 cm, the only recognizable nannofossils are Oligocene. In other samples, specimens of forms such as Discoaster variabilis, Hayaster perplexus, Discoaster exilis, and Discoaster braarudi suggest the lower to middle Miocene. According to correlations with the planktonic foraminifers, this interval (Cores 101-628A-13H through 101-628A-15H) should lie within the Discoaster kugleri Subzone of the Discoaster exilis Zone (CN5b). The nominant species for this subzone, however, was not observed within this interval.

Unit II (Cores 101-618A-16H through 101-628A-29X) consists of foraminiferal-nannofossil oozes and chalks with abundant, well-preserved nannofossil assemblages. Detailed biostratigraphic studies indicate that this unit includes sediments that represent almost the entire Oligocene and latest Eocene. All nannofossil subzones, with the exception of the Dictyococcites bisectus Subzone of the Sphenolithus ciperoensis Zone (CP19b), are present within this interval. This unit has been the subject of a separate shore-based nannofossil study (Moran and Watkins, this volume). In the interest of brevity, these results are not repeated here.

Three cores penetrating lithologic Unit III contain lower to middle Paleogene sediments. Samples 101-628A-30X-1, 80$81 \mathrm{~cm}$, and 101-628A-30X-2, 80-81 cm, contain nannofossil oozes and chalks with assemblages characteristic of the Reticulofenestra umbilica Zone (CP14; early middle Eocene). These include Reticulofenestra umbilica, Campylosphaera dela, Chiasmolithus solitus (rare), Nannotetrina quadrata, and Chiasmolithus grandis. The presence of rare $C$. solitus and $N$. quadrata suggests a subzonal assignment of CP14a. Section 628A-30X, CC contains a different assemblage, which appears to be a mixture of two zones. The co-occurrence of Discoaster lodoensis and rare Reticulofenestra umbilica suggests a mixture of middle and lower Eocene material. The dominant taxa appear to represent material from Zone CP12 (shipboard assignment), although some Zone CP14(?) taxa are present. Core 101-628A-31X consists of drilling breccia with sparse, poorly preserved specimens similar to those in Section 628A-30X, CC as well as some Oligocene taxa. Core 101-628A-32X contains $45 \mathrm{~cm}$ of sediment that was highly disturbed by drilling procedures. A sample of gray chalk within the core catcher contained late early Eocene assemblages similar to those described above. A green, mottled chalk yielded nannofossils including Fasciculithus tympaniformis (s.1.), Heliolithus kleinpelli, Heliolithus riedeli, Chiasmolithus bidens, and Discoaster mohleri. Absent from this assemblage were Discoaster nobilis and Discoaster multiradiatus. This association is characteristic of upper Paleocene nannofossil Zone CP6. This sample is derived from strata that lie between the FAD of $H$. riedeli and the FAD of $D$. nobilis. Berggren et al. (1985a) assign this interval to between 60 and $59.4 \mathrm{Ma}$.

\section{Site 629}

Penetration at Site 629 was only $16.5 \mathrm{~m}$. The coarse nature of the sediment in this area prevented effective coring, and the site was abandoned. Site 630 , a few kilometers downslope, was substituted for Site 629 . The core material recovered at this site consists of unlithified foraminiferal, skeletal packstones, grainstones, and rudstones. Evidence of sediment winnowing is abun- dant. The sparse nannofossil assemblages recovered by gravitational settling of this material contain Emiliania huxleyi, indicating nannofossil Zone CN15 (middle to late Pleistocene). The assemblages were too severely biased by sediment winnowing and sample preparation for accurate assessment of dominance by either $E$. huxleyi or the gephyrocapsids. As a result, recognition of the E. huxleyi Acme Zone of Gartner (1977) was not possible.

\section{Site 630}

Site 630 was the third of three successful sites drilled for the Little Bahama Bank slope transect. This site is the most proximal of the three, located on an interfluve between two major gullies on the upper part of the slope. Water depth at the site is approximately $807 \mathrm{~m}$. The stratigraphic section drilled at Site 630 has been divided into two lithostratigraphic units (Austin, Schlager, et al., 1986). As was expected from its proximal position, the sediments recovered at this site exhibit a large component of bank-derived aragonite and micrite. This dilution of pelagic material by bank-derived debris, and the resultant diagenetic environment, led to generally poor preservation and low abundances of nannofossils. Periodic decreases in the supply of bank-derived material during deposition of the sequence resulted in somewhat higher nannofossil abundance and (generally) better preservation. Samples from these intervals of lower bank-derived components have been instrumental in deciphering the biostratigraphic framework given below.

Emiliania huxleyi occurs through Core 101-630A-1H, indicating nannofossil Zone CN15 (middle to late Pleistocene). The abundance of this species in Sample 101-630A-1 H-1, 0-1 cm, is indicative of the E. huxleyi Acme Zone of Gartner (1977). By Sample 101-630A-1 H-1, 80-81 cm, the gephyrocapsids dominate the assemblage. This dominance reversal (here occurring between Samples 101-630A-1H-1, 0-1 cm, and 101-630A-1H-1, $80-81 \mathrm{~cm}$, has been dated as $0.085 \mathrm{Ma}$ by Berggren et al. (1985b). The remainder of Core 101-630A-1H is from the older part of Zone CN15. This zone may extend into the upper part of Core 101-630A-2H. Rare forms similar to E. huxleyi occur in Sample 101-630A-2H-1, 80-81 cm; however, poor preservation prohibits more exact taxonomic (and therefore biostratigraphic) placement. This problem is exacerbated by the fact that this sample is from an unlithified, bioturbated packstone into which younger nannofossils may have been introduced by bioturbation or drilling or both. In addition, reworking of older (late Neogene or earlier Quaternary), poorly preserved specimens of Pseudoemiliania lacunosa and Calcidiscus macintyrei is evident at the base of Core 101-630A-1H and at the top of Core 101-630A-2H.

Samples 101-630A-2H-1, 80-81 cm, and 101-630A-2H-3, 80$81 \mathrm{~cm}$, contain common specimens of Gephyrocapsa caribbeanica, Gephyrocapsa oceanica, and Pseudoemiliania lacunosa without unequivocal specimens of Emiliania huxleyi. This association suggests the latest Pliocene to early middle Pleistocene nannofossil Subzone CN14a. However, as stated before, the specimens of $P$. lacunosa are poorly preserved and may represent reworking. For this reason, these two samples are placed in Zone CN14 (latest Pliocene to middle Pleistocene) with no subzonal assignment. The larger gephyrocapsids $(G$. caribbeanica and $G$. oceanica) and the discoasters are absent from Samples $101-630 \mathrm{~A}-2 \mathrm{H}-5,80-81 \mathrm{~cm}$, through $101-630 \mathrm{~A}-3 \mathrm{H}-1,80-81 \mathrm{~cm}$, although $P$. lacunosa and Calcidiscus macintyrei occur. This association indicates nannofossil Subzone CN13a (late Pliocene). The apparent absence of nannofossil Subzone CN13b may be due to a disconformity or may be an artifact of sample spacing or masking by reworked specimens.

The interval from Sample 101-630A-3H-3, 80-81 cm, through 101-630A-7H-1, $80-81 \mathrm{~cm}$, has been tentatively assigned to the composite subzone $\mathrm{CN} 12 \mathrm{a}-\mathrm{c}$ (late early to early late Pliocene). 
Low nannofossil abundance, poor preservation, and evidence of reworking make more precise biostratigraphic assignment impossible for this interval. All samples in this interval contain Discoaster brouweri, Discoaster triradiatus, and Discoaster pentaradiatus. In some samples, these are the only biostratigraphically significant taxa present. Other samples contain additional taxa whose stratigraphic position is anomalous. For example, Sample 101-630A-4H-5, 80-81 cm, contains a sparse, poorly preserved assemblage with $D$. brouweri, $D$. triradiatus, and $D$. pentaradiatus. Sample 101-630A-5H-1, 80-81 cm, contains a richer, better preserved assemblage containing these species in addition to Discoaster surculus, Discoaster asymmetricus, and Discoaster tamalis. The next, stratigraphically lower, sample (Sample 101-630A-5H-3, 80-81 cm) contains a more poorly preserved assemblage with only three discoasters: $D$. brouweri, $D$. triradiatus, and $D$. pentaradiatus. No strong evidence is available to determine whether reworking or preservation bias is at work to yield this anomalous succession of assemblages. Thus, this interval has been given the tentative assignment to nannofossil subzone CN12a-c (late Pliocene) until other, more conclusive evidence surfaces.

The interval from Sample 101-630A-7H-3, 80-81 cm, through Core $101-638 \mathrm{~A}-14 \mathrm{H}$ has been assigned to the combined nannofossil zones CN10-11 (latest Miocene through late early Pliocene). The quality of the nannofossil assemblages from this interval is generally poor, so that the presence or absence of the biostratigraphically important ceratoliths cannot be reliably ascertained. The presence of Reticulofenestra pseudoumbilica and Sphenolithus abies and the absence of Discoaster quinqueramus and Discoaster berggreni in assemblages from this interval do, however, allow a CN10-11 zonal assignment. The presence or absence of Discoaster asymmetricus, which could yield a more precise biostratigraphic assignment, cannot be trusted owing to evidence of downhole contamination in many of the samples.

Discoaster quinqueramus and Discoaster berggreni are present in the underlying interval from Core 101-630A-15H through Sample 101-630A-24X-3, $80-81 \mathrm{~cm}$. These two species are characteristic of nannofossil Zone CN9 (latest Miocene). Subzonal division is possible owing to slightly higher abundances of nannofossils in the sediment. In addition, the criteria for division of Subzones CN9a and CN9b are the first occurrences of Amaurolithus primus and Amaurolithus delicatus. Because these taxa were the first of the ceratolith group to evolve, the presence of any ceratolith (regardless of preservation, which prohibits specific assignment) with $D$. quinqueramus is evidence of Subzone $\mathrm{CN} 9 \mathrm{~b}$. Using this criterion, the generally poor preservation does not prohibit division of this zone into two subzones between Samples 101-630A-19H-3, 80-81 cm, and 101-630A-19H-5, 80$81 \mathrm{~cm}$. Thus, Core 101-630A-15H through Sample 101-630A$19 \mathrm{H}-3,80-81 \mathrm{~cm}$, belongs to the Amaurolithus primus Subzone (CN9b), whereas the interval from Samples 101-630A-19H-5, $80-81 \mathrm{~cm}$, through $101-630 \mathrm{~A}-24 \mathrm{X}-3,80-81 \mathrm{~cm}$, belongs to the Discoaster berggreni Subzone $(\mathrm{CN} 9 \mathrm{a})$. Samples from the remainder of Hole 630A (from Section 101-630A-24X, CC through Core 101-630A-26X) are essentially barren of nannofossils and cannot be assigned to a biostratigraphic interval.

\section{Site 631}

Site 631 is one of three sites drilled to investigate the stratigraphic development of the steep southwestern slope of southeastern Exuma Sound. The site is the most proximal of the three in the Exuma Sound transect, located less than $6.5 \mathrm{~km}$ from Great Exuma Island. Water depth at the site is approximately $1081 \mathrm{~m}$. The stratigraphic section drilled consists of approximately $244 \mathrm{~m}$ of periplatform ooze and chalk. Bank-derived aragonite is common to abundant throughout the section. Hydrogen sulfide gas, apparently resulting from active sulfate re- duction, was ubiquitous in the sediment (Austin, Schlager, et al., 1986). The combination of high aragonite contents, probable high original high-magnesium calcite contents, and active sulfate reduction in the sediment resulted in a diagenetic environment that was unfavorable for the preservation of planktonic microfossils (Plate 1, Figs. 3 and 4). These diagenetic factors, in combination with the general dilution of planktonic assemblages by bank-derived debris, rendered most of the Site 631 material unsuitable for high-quality biostratigraphic studies of plankton. Only samples with relatively little platform-derived material exhibit good nannofossil preservation (Plate 1, Figs. 1 and 2).

The presence of Emiliania huxleyi in nannofossil assemblages in the interval from Core 101-631A-1H through Sample 101-631A-1H-3, 80-81 cm, indicates nannofossil Zone CN15. These assemblages are dominated by members of the genus $\mathrm{Ge}$ phyrocapsa. This indicates that the $E$. huxleyi Acme Zone of Gartner (1977) was not recovered at this site. This interval is correlated to the middle Pleistocene (in part) to the late (but not latest) Pleistocene. Both E. huxleyi and Pseudoemiliana lacunosa are absent from Section 101-631A-1H-4 through Sample $101-631 \mathrm{~A}-2 \mathrm{H}-1,80-81 \mathrm{~cm}$, although the rest of the assemblage includes typical Pleistocene nannofossils. This is indicative of the middle Pleistocene nannofossil Subzone CN14b. The LAD of Pseudoemiliania lacunosa is in Sample 101-631A-2H-3, 80$81 \mathrm{~cm}$. This sample, and the interval downsection through Core 101-631A-2H, are included in nannofossil Subzone CN14a, which is correlative to early through early middle Pleistocene. Sample 101-631A-3H-1, 80-81 cm, contains P. lacunosa, Gephyrocapsa caribbeanica, and the small gephyrocapsids, but lacks Gephyrocapsa oceanica and the discoasters. This assemblage is indicative of nannofossil Subzone CN13a (latest Pliocene). It is not known whether Subzone CN13b is missing at Site 631 or if this short subzone is represented in the overlying $80 \mathrm{~cm}$ in Core 101-631A-3H.

The core interval from Samples 101-631A-3H-3, 80-81 cm, through 101-631A-5H-5, 80-81 cm, contains sparse and generally poorly preserved nannofossil assemblages that include $D i s$ coaster brouweri, Discoaster surculus, Discoaster pentaradiatus, and Discoaster tamalis without Reticulofenestra pseudoumbilica or Sphenolithus abies. This assemblage is characteristic of the Discoaster tamalis Subzone of the D. brouweri Zone (CN12a). This subzone correlates to part of the early late Pliocene. The presence of this subzone immediately underlying Subzone CN13a in Section 101-631A-3H-1 indicates an unconformity with a hiatus of at least $0.7 \mathrm{~m} . \mathrm{y}$.

Biostratigraphic relationships below Core 101-631A-5H are difficult to define exactly owing to the sparse and poorly preserved nature of the nannofossil assemblages. In the periplatform sediments of Hole 631A the ceratoliths are so rare as to be unreliable for biostratigraphic purposes. As a result, only the first common occurrence of Discoaster asymmetricus can be used to subdivide the lower part of Hole 631A. The interval from Section 101-631A-5H, CC through Core 101-631A-16H contains sparse, poorly preserved assemblages that include $R e$ ticulofenestra pseudoumbilica, Sphenolithus abies, Sphenolithus neoabies, and $D$. asymmetricus. Given the lack of usable information on the ceratoliths, this association indicates the interval from Subzone CN10c through Zone CN11 (late early Pliocene). Preservation deteriorates with depth in this interval. As a result, the first common occurrence of Discoaster asymmetricus is difficult to pinpoint. The assignment of this biostratigraphic datum to Section 101-631A-16H, CC is, therefore, somewhat questionable. Discoaster asymmetricus does not appear to be present below Core 101-631A-17H, nor does Discoaster quinqueramus. These relationships suggest the lower portion of the Amaurolithus tricorniculatus Zone (CN10a-b; early Pliocene). 
Increasingly poor preservation and poor core recovery make precise age determination by nannofossil biostratigraphy impossible below Core 101-631A-18H, although the character of a few poorly preserved assemblages suggests a middle or late Miocene age.

\section{Site 632}

Site 632 is the second of three sites drilled to examine the slope stratigraphy of southeastern Exuma Sound. Site 632 is the deepest (1996 m water depth) and most distal of the three sites on the Exuma Sound transect. Two holes were drilled at this site. The first (Hole 632A) penetrated approximately $141 \mathrm{~m}$ of section. The second (Hole 632B) began core recovery at approximately the total depth of Hole 632A, yielding a composite stratigraphic section of approximately $280 \mathrm{~m}$. The drilled section has been divided into three lithostratigraphic units. Aragonite is present throughout the section (Austin, Schlager, et al., 1986). This may have contributed to the generally advanced state of diagenesis in the planktonic microfossils. The assemblages are generally sparse throughout the section, having been largely diluted by the influx of platform-derived micrite and skeletal debris.

Emiliania huxleyi is present from Samples 101-632A-1H-1, $0-1 \mathrm{~cm}$, through $101-632 \mathrm{~A}-1 \mathrm{H}-3,80-81 \mathrm{~cm}$, indicating middle Pleistocene to Holocene nannofossil Zone CN15. This species dominates the assemblages in Samples 101-632A-1H-1, 0-1 cm, and $101-632 \mathrm{~A}-1 \mathrm{H}-1,80-81 \mathrm{~cm}$. This assemblage indicates the Emiliania huxleyi Acme Zone of Gartner (1977). Assemblages from Sample 101-632A-1H-2, 80-81 cm, and 101-632A-1H-3, $80-81 \mathrm{~cm}$, are dominated by the gephyrocapsids, especially $\mathrm{Ge}$ phyrocapsa caribbeanica. The change in dominance from $\mathrm{G}$. $\mathrm{ca}$ ribbeanica to $E$. huxleyi occurs during oxygen isotope stage 5, at approximately $0.085 \mathrm{Ma}$ in tropical regions (Thierstein et al., 1977). In addition to the autochthonous assemblage, a few specimens of reworked Neogene nannofossils (such as Discoaster brouweri) are present in these samples.

Assemblages from the interval of Samples 101-632A-1H-4, $80-81 \mathrm{~cm}$, to 101-632A-2H-1, 80-81 cm, contain Gephyrocapsa oceanica and Geophyocapsa caribbeanica but lack E. huxleyi and Pseudoemiliania lacunosa. This is indicative of nannofossil Subzone $\mathrm{CN} 14 \mathrm{~b}$, which is correlative with the middle Pleistocene. Reworked Neogene nannofossils occur in trace amounts in this interval. Pseudoemiliania lacunosa occurs with G. oceanica and $G$. caribbeanica throughout the interval from Samples 101$632 \mathrm{~A}-2 \mathrm{H}-3,80-81 \mathrm{~cm}$, to $101-632 \mathrm{~A}-5 \mathrm{H}, \mathrm{CC}$. This association is characteristic of nannofossil Subzone $\mathrm{CN} 14 \mathrm{a}$, which correlates to the early and early middle Pleistocene. Reworking of Neogene and especially Oligocene nannofossils is common in some samples, such as Section 101-632A-4H, CC, within this interval. A possible unconformity, including nannofossil Zone $\mathrm{CN} 13$ (latest Pliocene to earliest Pleistocene), separates this interval from the underlying part of the section.

Core 101-632A-6H contains assemblages that represent at least four nannofossil subzones, although some of these subzones may be artifacts of reworking. The interval from Samples 101-632A-6H-1, 0-1 cm, through 101-632A-6H-2, 80-81 cm, contains Discoaster brouweri without any other discoasters, indicating Subzone $\mathrm{CN} 12 \mathrm{~d}$. Oligocene nannofossils are common in this interval, indicating some reworking. It is possible that part of this interval may lie in the overlying Zone CN13, with the discoasters being a reworked component. Sample 101-632A$6 \mathrm{H}-3,80-81 \mathrm{~cm}$, contains Discoaster pentaradiatus in addition to $D$. brouweri but without other discoasters. This association is characteristic of Subzone CN12c. Samples from Sections 101632A-6H-4 and 101-632A-6H-5 contain these discoasters with the addition of Discoaster surculus and Discoaster tamalis, indicating Subzone CN12a. Finally, Samples 101-632A-6H-7, 25-
$26 \mathrm{~cm}$, through 101-632A-6H, CC are included in the underlying composite zone CN10d-CN11, as described below. This sequence, although apparently in proper stratigraphic order, is not as simple as it appears. There are apparent reversals in the biostratigraphic order within Core 101-632A-6H. For example, Sample 101-632A-6H-5, 24-25 cm, contains only Discoaster brouweri $(\mathrm{CN} 12 \mathrm{~d})$, although it is intercalated between sample zones that yield both $D$. brouweri and $D$. pentaradiatus $(\mathrm{CN} 12 \mathrm{c})$. A similar situation is evident in Section 101-632A-6H, CC. This sample has Subzone CN12a assemblages, although it is surrounded above and below by samples with Zone CN11 assemblages. This sequence suggests multiple, short-lived episodes of reworking during the late Pliocene.

The interval from Samples 101-632A-6H-7, 25-26 cm, through 101-632A-12H-4, $80-81 \mathrm{~cm}$, contains common but poorly preserved nannofossil assemblages. Sample 101-632A-6H-7, $25 \mathrm{~cm}$, through Section 101-632A-9H, CC contains assemblages that include Reticulofenestra pseudoumbilica, Sphenolithus abies, Sphenolithus neoabies, and Discoaster asymmetricus. These assemblages have been assigned to the combined nannofossil zones CN10d-CN11 (middle early Pliocene) because it was impossible to ascertain reliably whether Amaurolithus tricorniculatus or Amaurolithus primus was present as in-situ specimens. Several specimens of Amaurolithus sp. cf. A. tricorniculatus were found in several samples (e.g., Sample 101-632A-8H-1, 80-81 cm), suggesting Zone $\mathrm{CN} 11$. The preservational state of these rare specimens, however, casts doubt as to their true taxonomic affinities and their autochthonous nature. Reworking of common to abundant Oligocene nannofossils was evident in most of the samples examined from this interval. No age-diagnostic nannofossil assemblages were present in the small amount of winnowed sediment recovered in Cores 101-632A-10H and 101$632 \mathrm{~A}-11 \mathrm{H}$. Based on stratigraphic relationships, these two cores are included within nannofossil Zone $\mathrm{CN} 10$ (middle early Pliocene).

Preservation improved to moderate levels in Core 101632A-12X, allowing a more exact biostratigraphic assignment. Samples 101-632A-12X-1, 80-81 cm, and 101-632A-12X-3, 80$81 \mathrm{~cm}$, contain Amaurolithus primus and Amaurolithus delicatus but lack Discoaster berggreni, Discoaster quinqueramus, and Discoaster asymmetricus. The presence of $A$. primus and the lack of the three discoasters indicate Subzones CN10a-c. The presence of $A$. delicatus, however, suggests the earlier portion of this interval, probably Subzone CN10a or early CN10b. This interval correlates to the early early Pliocene. Discoaster berggreni, Amaurolithus primus, Amaurolithus delicatus, and Discoaster sp. cf. D. quinqueramus occur in Sample 101-632A$12 \mathrm{X}-4,80-81 \mathrm{~cm}$, suggesting the Amaurolithus primus Subzone of the Discoaster quinqueramus Zone (CN9b; late Miocene). Undoubted specimens of $D$. quinqueramus occur with $D$. berggreni and the amauroliths in underlying Sample 101-632A-12X-5, $80-81 \mathrm{~cm}$, indicating Subzone CN9b.

Nannofossil preservation deteriorates in the lower part of Hole 632A and throughout Hole 632B. Scattered samples contain assemblages that are somewhat richer, more diverse, and better preserved. It is largely from these few samples that the following biostratigraphy has been constructed. The intervals from Sample 101-632A-12X-5, 80-81 cm, through Core 101$632 \mathrm{~A}-16 \mathrm{X}$ and from Core 101-632B-1R through Sample 101632B-2R-1, 80-81 cm, contain assemblages that include Discoaster berggreni, Discoaster quinqueramus, Amaurolithus delicatus, and Amaurolithus primus, indicating Subzone CN9b (latest Miocene). The amauroliths are apparently absent below Sample 101-632B-2R-1, 80-81 cm, although this is difficult to ascertain absolutely because of poor preservation. However, poorly preserved specimens assigned to Discoaster quinqueramus and/or Discoaster berggreni persist to the base of the hole 
(Core 101-632B-17R). Based on this evidence, this lowest interval is assigned to nannofossil Subzone CN9a, which correlates to the middle late Miocene.

\section{Site 633}

Site 633 was the third of three sites drilled to investigate the stratigraphic record of Exuma Sound slope. Site 633 was drilled to examine the record of the toe-of-slope environment in a water depth of approximately $1681 \mathrm{~m}$. Twenty-four cores were drilled for a total single penetration of approximately $227 \mathrm{~m}$. Three lithostratigraphic units were designated within the drilled section. Unit I (Core 101-633A-1H to Section 101-633A-6H-4) consists of periplatform oozes rich in nannofossil and bank-derived aragonite needles. Unit II (Section 101-633A-6H-4 through Core 101-633A-16X) consists of periplatform oozes and chalks with a significantly higher content of micrite and/or aragonite needles. Diagenetic alteration and lithification of this unit are significantly greater than in the overlying unit. Unit III consists of interbedded periplatform limestones and calciturbidites, with the latter lithotype forming approximately $30 \%$ of the recovered section (Austin, Schlager, et al., 1986). Excellent recovery of Unit I prompted an intensive study of this interval utilizing oxygen-isotope methods, carbonate mineralogy, magnetostratigraphy, planktonic-foraminiferal biostratigraphy (using the Globorotalia menardii Complex stratigraphy of Ericson and Wollin, 1968), and nannofossil biostratigraphy (Droxler et al., this volume). In the course of this work, nannofossil sampling at intervals of approximately $50 \mathrm{~cm}$ provided a detailed biostratigraphic framework. The remainder of Hole 633 was examined using a more widely spaced sampling interval.

Emiliania huxleyi occurs from Sample 101-633A-1H-1, 0$1 \mathrm{~cm}$, through Sample 101-633A-1H-4, 10-11 cm, indicating nannofossil Zone CN15 (late middle Pleistocene through Holocene). Oxygen-isotope investigation of the Hole 633A section (Droxler et al., this volume) places this FAD in oxygen-isotope stage 8 , a correlation that is in precise agreement with that reported by Thierstein et al. (1977). Emiliania huxleyi is the dominant species in the assemblages from Sample 101-633A-1H-1, 0-1 cm, through Sample 101-633A-1H-2, 10-11 cm, although there is a distinct decrease in the relative abundance of $E$. huxleyi in the lowest sample within this interval. The reversal in dominance between $E$. huxleyi and the larger gephyrocapsids (especially Gephyrocapsa caribbeanica) occurs between Sample 101-633A$1 \mathrm{H}-2,10-11 \mathrm{~cm}$, and Sample 101-633A-1H-2, 50-51 cm. This corresponds to oxygen-isotope stage 5 in the Hole $633 \mathrm{~A}$ material (Droxler et al., this volume), which is in approximate agreement with the results of Thierstein et al. (1977). The latter date this event as approximately $0.085 \mathrm{Ma}$ (in tropical and subtropical waters). Preservation within this interval at Site 633 is excellent.

The interval from Sample 101-633A-1H-4, 50-51 cm, through Section 101-633A-1H, CC lacks both E. huxleyi and Pseudoemiliania lacunosa but contains other typical Pleistocene nannofossils such as Gephyrocapsa oceanica and Gephyrocapsa caribbeanica. This is characteristic of the Ceratolithus cristatus nannofossil Subzone (CN14b), which correlates to part of the middle Pleistocene ( 0.275 to $0.474 \mathrm{Ma}$, according to Berggren et al., 1985b). Preservation within this interval is generally very good, especially in those samples with lower concentrations of aragonite needles.

The LAD of $P$. lacunosa occurs between Section 101-633A$1 \mathrm{H}, \mathrm{CC}$ and Sample 101-633A-2H-1, $10 \mathrm{~cm}$. The correspondence of a zonal boundary with a core boundary is often indicative of missing section resulting from drilling disturbance. This seems to be true in this case, as the core break also corresponds to the boundary between isotope stages 10 and 11 (Droxler et al., this volume). Consultation of the drilling and core-recovery records suggests that at least $60 \mathrm{~cm}$ of section is missing at this core break (Austin, Schlager, et al., 1986). The cored interval containing assemblages with both $P$. lacunosa and $G$. oceanica (nannofossil Subzone CN14a) spans Samples 101-633A-2H-1, $100-101 \mathrm{~cm}$, through 101-633A-3H-3, 50-51 cm. Gephyrocapsa oceanica (s.s.) does not occur below this interval, indicating that the FAD of $G$. oceanica is between Sample 101-633A-3H-3, $50-51 \mathrm{~cm}$, and Sample 101-633A-3H-3, 100-101 cm. Berggren et al. (1985b) date this first-appearance datum at $1.68 \mathrm{Ma}$.

Assemblages including P. lacunosa and Gephyrocapsa caribbeanica but lacking $G$. oceanica (s.s.) occur from Sample 101633A-3H-3, 100-101 cm, through Sample 101-633A-5H-1, 10$11 \mathrm{~cm}$. This is characteristic of nannofossil Subzone CN13b, which correlates to the latest Pliocene of Berggren et al. (1985b), although other authors (such as Okada and Bukry, 1980) would consider this subzone as early Quaternary. The FAD of $G$. $c a$ ribbeanica occurs between Samples 101-633A-5H-1, 10-11 cm, and $101-633 \mathrm{~A}-5 \mathrm{H}-1,53-54 \mathrm{~cm}$. This first-occurrence datum was dated as $1.74 \mathrm{Ma}$ by Berggren et al. (1985b). The LAD of Calcidiscus macintyrei also occurs within this interval, between Samples 101-633A-4H-1, 90-91 cm, and 101-633A-4H-2, 10-11 cm. This last-appearance datum was assigned an age of $1.45 \mathrm{Ma}$ (early Pleistocene) by Berggren et al. (1985b).

The interval from Sample 101-633A-5H-1, 53-54 cm, through Sample 101-633A-5H-3, 50-51 cm, contains numerous small gephyrocapsids, but neither $G$. caribbeanica nor a significant number of discoasters. This is indicative of the latest Pliocene nannofossil Subzone CN13a. Very rare specimens of Discoaster brouweri and Discoaster triradiatus occur in samples near the base of this interval (Samples 101-633A-5H-3, 10-11 cm, and $101-633 \mathrm{~A}-5 \mathrm{H}-3,50-51 \mathrm{~cm})$. These specimens constitute significantly less than $0.01 \%$ of the total assemblage. At these low levels of abundance, it is impossible to separate autochthonous specimens from reworked ones, based solely on nannofossil evidence. Magnetostratigraphic evidence suggests that the samples in question are close to the LAD of $D$. brouweri and D. triradiatus. All but the lowest few centimeters of Section 101-633A5H-3 lies within the Olduvai Subchron (Sager, this volume; Droxler et al., this volume). Berggren et al. (1985b, p. 287) place the LAD of $D$. brouweri and $D$. triradiatus at or near the base of this subchron, noting that it may occur within the Olduvai. Finer stratigraphic resolution is not possible at present. Because no independent criteria yield a definitive answer, a subjective decision must be made as to whether these discoasters are autochthonous. Because of their very rare abundance in the samples in question, we consider these discoasters to be reworked.

Samples 101-633A-5H-3, 105-106 cm, through 101-633A$5 \mathrm{H}-5,132-133 \mathrm{~cm}$, contain assemblages that include common Discoaster brouweri and Discoaster triradiatus but no other discoasters. This association is characteristic of nannofossil Subzone $\mathrm{CN} 12 \mathrm{~d}$, which correlates to part of the late Pliocene. This LAD of $D$. brouweri and D. triradiatus (between Samples 101$633 \mathrm{~A}-5 \mathrm{H}-3,50-51 \mathrm{~cm}$, and $101-633 \mathrm{~A}-5 \mathrm{H}-3,105-106 \mathrm{~cm}$ ) was assigned an age of $1.9 \mathrm{Ma}$ by Berggren et al. (1985b). The presence of Gephyrocapsa aperta and the absence of Discoaster asymmetricus within these assemblages indicate the upper portion of Subzone CN12d. Berggren et al. (1985b) consider these nannofossil datums to be approximately isochronous events that occurred at $2.2 \mathrm{Ma}$. This suggests that the entire interval from Sample 101-633A-5H-3, 105-106 cm, to Sample 101-633A-5H-5, $132-133 \mathrm{~cm}$, correlates to an age of 1.9 to $<2.2 \mathrm{Ma}$. This age assignment is at least partially corroborated by magnetostratigraphic evidence. Sager (this volume) recognizes the Reunion Subchron (2.0 Ma) within the lower half of Section 101-633A$5 \mathrm{H}-4$. Extrapolation of the average rate of sediment accumulation for this interval (11-12 m/m.y.; see Droxler et al., this volume) from the middle of Section 101-633A-5H-4 to the base of 
Subzone CN12d (at approximately Sample 101-633A-5H-5, 132$133 \mathrm{~cm}$ ) yields an age slightly less than $2.1 \mathrm{Ma}$. A few, relatively poorly preserved late Paleogene nannofossils (such as Dictyococcites abisectus and Reticulofenestra bisecta) occur in most samples within this subzone.

A significant unconformity underlies Subzone CN12d at this site. This disconformity approximately corresponds to the section break between Sections 101-633A-5H-5 and 101-633A-5H-6. Samples below this stratigraphic break also exhibit significantly poorer preservation and sparse nannofossil assemblages. These assemblages include Reticulofenestra pseudoumbilica, Discoaster variabilis, Sphenolithus abies, and Sphenolithus neoabies as well as rare, poorly preserved specimens of Amaurolithus primus and Amaurolithus tricorniculatus. Missing from these assemblages are species such as Discoaster quinqueramus and Discoaster berggreni. These taxa indicate the latest Miocene to early Pliocene Amaurolithus tricorniculatus Zone (CN10). Poor preservation and sparse assemblages make division of this interval into subzones difficult. Rare, poorly preserved specimens assignable to Discoaster asymmetricus occur within Cores 101$633 \mathrm{~A}-6 \mathrm{H}$ through 101-633A-8H, suggesting Subzone CN10d (early Pliocene). Assuming that Subzone CN10d is present at this site, the disconformity between Sections 101-633A-5H-5 and $101-633 \mathrm{~A}-5 \mathrm{H}-6$ represents a minimum of $1.5 \mathrm{~m}$.y. Nannofossil Zone CN10 is represented from Sample 101-633A-5H-6, 14-15 cm, through Sample 101-633A-16X-3, 80-81 cm. Reworked Oligocene nannofossils occur in varying amounts throughout this interval. In some samples, such as 101-633A-13X, CC, they are as abundant as the autochthonous Neogene specimens. Reworking of nannofossils from the underlying Discoaster quinqueramus Zone (CN9) is frequently evident within the lower three cores of this interval (Cores 101-633A-14X through 101633A-16X). These reworked Miocene nannofossils usually occur as rare, poorly preserved specimens. In Section 101-633A-14X, CC, however, numerous moderately preserved specimens of Discoaster quinqueramus and Discoaster berggreni occur with the autochthonous (and more poorly preserved) Zone $\mathrm{CN} 10$ assemblage.

In general, nannofossil preservation deteriorates in the lower part of Hole $633 \mathrm{~A}$, leading to difficulty in age determination. A few assemblages between Sample 101-633A-16X-5, 80-81 cm, and Section 101-633A-22X, CC exhibit somewhat better preservation and nannofossil abundance. These few samples contain Discoaster quinqueramus, Discoaster berggreni, Amaurolithus delicatus, and Amaurolithus primus, indicating nannofossil Subzone CN9b (late Miocene). Samples from Cores 101-633A-23X and 101-633A-24X were barren of nannofossils and therefore cannot be dated by this method.

\section{Site 634}

Site 634, a re-occupation of DSDP site 98 (Hollister, Ewing, et al., 1972), lies in $2835 \mathrm{~m}$ water depth on the steep southeastern slope of Northeast Providence Channel. Following retrieval of a mud-line core, the hole was washed to approximately $144 \mathrm{~m}$ sub-bottom. At this depth, continuous coring commenced and continued to a total depth of approximately $480 \mathrm{~m}$ sub-bottom. Four lithostratigraphic units were designated for the cored interval in Hole 634A (Austin, Schlager, et al., 1986).

Unit I (periplatform ooze) contains nannofossil assemblages that are dominated by Emiliania huxleyi. This is characteristic of the E. huxleyi Acme Zone of Gartner (1977), indicating that this sediment is less than 85,000 years old. In sharp lithologic contact with the base of Unit I are oozes and chalks of Unit II containing diverse, rich, well-preserved assemblages of $\mathrm{Amau}$ rolithus primus, Amaurolithus delicatus, Amaurolithus amplificus, Amaurolithus tricorniculatus, and Discoaster asymmetricus. This association is diagnostic for the Amaurolithus delica- tus Subzone of the Amaurolithus tricorniculatus Zone (CN10d), which has been correlated with a relatively narrow interval in the lower Pliocene of between 4.1 to 3.7 Ma (Berggren et al., 1985b). Trace amounts of Paleogene species such as Dictyococcites bisecta, Reticulofenestra abisecta, and Reticulofenestra umbilica are present in samples from this unit.

Unit III (nannofossil chalk and chert) was cored at the base of a thick washed interval. Sections 101-634A-2R-1 through 101-634A-2R-3 contain rich, moderately to well-preserved nannofossil assemblages that include Discoaster multiradiatus, Discoaster diastypus, Tribrachiatus orthostylus, and Zygrhablithus bijugatus, indicating nannofossil Subzone CP9b (early Eocene). Section 101-634A-2R, CC contains D. multiradiatus, D. diastypus, T. orthostylus, and T. contortus. The co-occurrence of these four species in the absence of Zygrhablithus bijugatus indicates the lowest Eocene nannofossil Subzone CP9a. In samples from Cores 101-634A-3R through 101-634A-4R, T. orthostylus and Discoaster diastypus are absent, and T. contortus is rare. This suggests that Cores 101-634A-3R and 101-634A-4R are in the lowest part of Subzone CP9a. Braarudosphaerids become an important component of the assemblages in these two cores, suggesting a significant neritic influence on the earliest Eocene surface waters in this area.

Recovery was very poor through Unit IV, ranging from $0 \%$ to $13 \%$ and averaging $3.4 \%$ (Austin, Schlager, et al., 1986). Most of the material recovered consists of platform-derived skeletal grainstones and rudstones. Nannofossil-bearing sediment (predominantly chalk) is restricted to only a few cores within this unit. The following biostratigraphy is based on these few samples. Samples 101-634A-6R-1, 23-24 cm, and 101-634A6R, CC contain nannofossil assemblages that include Tranolithus phacelosus, Quadrum trifidum, Quadrum sissinghi, Broinsonia parca, and probable specimens of Reinhardtites levis. This association, in the absence of Eiffellithus eximius and Reinhardtites anthophorus, is indicative of the lower portion of the Tranolithus phacelosus Zone. This zone is correlative to the latest Campanian. In Section 101-634A-7R, CC, this assemblage is joined by both Eiffellithus eximius and Reinhardtites anthophorus, indicating the upper Campanian Quadrum trifidum Zone. Sections 101-634A-11R, CC and 101-634A-14R, CC no longer contain Quadrum trifidum but do have Lithastrinus grilli. The presence of $L$. grilli and $Q$. sissinghi without $Q$. trifidum is diagnostic of the Quadrum sissinghi Zone (upper Campanian). Quadrum sissinghi is no longer present in Section 101-634A$17 \mathrm{R}, \mathrm{CC}$, although Ceratolithoides aculeus is still present. This is diagnostic of the lower Campanian Ceratolithoides aculeus nannofossil zone. Samples 101-634A-22R, CC, 101-634A-23R, CC, 101-634A-28R-1, 129-130 cm, 101-634A-28R, CC, 101-634A$30 \mathrm{R}, \mathrm{CC}$, and 101-634A-31R-1, 51-53 cm, all contain assemblages that include Broinsonia parca but lack Ceratolithoides aculeus and Marthasterites furcatus. This is characteristic of the Calculites ovalis Zone of the lower Campanian. However, the distribution of $M$. furcatus is known to be paleoecologically limited (Perch-Nielsen, 1985), so that its absence may not be of biostratigraphic significance at this site. Therefore, a composite zonal assignment of $C$. ovalis/A. parcus is given to this interval. Reworking of older nannofossil assemblages is suggested by the presence of Eprolithus floralis and Quadrum gartneri in some of these samples.

\section{Site 635}

Site 635 lies in the thalweg of Northeast Providence Channel in a water depth of approximately $3470 \mathrm{~m}$. Three lithologic units were recovered in drilling this site: interbedded periplatform ooze and calciturbidites (Unit I), one or more sediment gravity-flow deposits containing a chaotic mixture of lithologies (Unit II), and rhythmically bedded light and dark (organic-rich) 
limestones with massive sediment gravity-flow deposits in its lower (recovered) part (Unit III). Recovery of Unit I was most complete in Hole 635A, whereas Units II and III were most complete from Hole 635B (Austin, Schlager, et al., 1986).

Unit I contains Quaternary nannofossil assemblages with reworked Pliocene forms. Core 101-635A-1R contains assemblages with Emiliania huxleyi, Gephyrocapsa oceanica, and Gephyrocapsa caribbeanica, indicating the late Quaternary Emiliania huxleyi Zone (CN15). The dominance of the assemblages by $E$. huxleyi is characteristic of the E. huxleyi Acme Zone of Gartner (1977), which correlates to the latest Quaternary. This zone is represented only by Sample 101-635B-1R-1, 0-1 cm, in Hole 635B. This uppermost Quaternary sediment lies directly on lithologic Unit II in Hole 635B. In Hole 635A, however, an additional Quaternary zone is preserved between the latest Quaternary material and Unit II. Core 101-635A-2R contains nannofossils that include Gephyrocapsa oceanica, Gephyrocapsa caribbeanica, and Pseudoemiliania lacunosa. This association indicates early Quaternary Zone CN13.

Unit II is lithologically and biostratigraphically chaotic in character. In Hole 635B, where it is best represented, it contains various clasts of silicified limestone, chalk, rudist limestone, skeletal grainstone, packstone, and rudstone floating in a matrix of pyrite-bearing packstone and/or chalk. Biostratigraphic ages for these clasts include (?)Early Cretaceous, Cenomanian, Turonian, Santonian-Campanian, late Paleocene, and mixed Oligocene-Neogene. The biostratigraphic age of the matrix also is variable, although never younger than Pliocene. Some of this material at the base of Core 101-635B-4R appears to be in-situ pelagic sediment. The nannofossil assemblage in this interval (Section 101-635B-4R, CC) includes Discoaster asymmetricus, Reticulofenestra pseudoumbilica, and Sphenolithus abies without any of the species of Amaurolithus. This is characteristic of the Reticulofenestra pseudoumbilica Zone (CN11), which correlates to part of the late early Pliocene. If the assumption that this sample represents in-situ pelagic sediment is correct, then the emplacement of the sediment gravity deposit (Unit II) took place during the late early Pliocene. No nannofossil-bearing sediment was recovered in Cores 101-635B-5R through 101635B-7R.

Unit III is more stratigraphically coherent, although evidence of sediment gravity-flow deposition is present in the lower part of the unit. The interval from Cores 101-635B-8R through 101635B-12R contains nannofossil assemblages that include Eiffellithus spp. 2 and 3 of Perch-Nielsen $(1979,1985)$ but not Lithraphidites acutus nor Microrhabdulus decoratus (Table 3). This assemblage is characteristic of the Eiffellithus turriseiffeli Zone, which correlates with the late Albian through early Cenomanian. Additional biostratigraphic information allows a more precise age determination for this interval. The absence of Corollithion kennedyi and the presence of Braarudosphaera africana (in Sample 101-635B-8R-1, 53-54 cm) suggest that the entire interval is Albian. The validity of this suggestion is strengthened by the rather primitive nature of the eiffellithids within this interval. The absence of Hayesites albiensis from Samples 101635B-8R-1, 53-54 cm, through 101-635B-12R-1, 109-110 cm, indicates that this interval is within the Prediscosphaera spinosa Subzone of the Eiffellithus turriseiffeli Zone. Hayesites albiensis appears in the lowest two samples of the zone (Samples 101635B-12R-2, 70-71 cm, and Section 101-635B-12R, CC), indicating that this lowest portion is within the Hayesites albiensis Subzone of the Eiffellithus turriseiffeli Zone, which correlates to the late (but not latest) Albian.

Lithologic Unit III contains two distinct lithologic subunits: an upper subunit of rhythmically bedded gray limestones and organic-rich dark limestones (Subunit IIIA), and a lower subunit containing two major sediment gravity deposits interbed- ded with rhythmically bedded dark and light limestones (Subunit IIIB). The lithologic change between Subunits IIIA and IIIB is mirrored by a significant biostratigraphic break (between Samples 101-635B-12R, CC and 101-635B-13R-2, 77-78 cm). Eiffellithus spp. are not present below Core 101-635B-12R, and the majority of Prediscosphaera columnata specimens are relatively small. This indicates the Prediscosphaera columnata Zone (early to middle Albian). In addition, no specimens of Tranolithus phacelosus or Corollithion signum are present in this interval (Samples 101-635B-13R-2, 77-78 cm, through 101-635B$14 \mathrm{R}, \mathrm{CC})$. The absence of these two species indicates the lower portion of the $P$. columnata Zone, which correlates to the late early to early middle Albian. Thus, the lithologic break between Subunits IIIA and IIIB represents a biostratigraphic gap in which at least one informal nannofossil subzone is missing. Nannoconids are relatively abundant in the lower subunit (IIIB), suggesting a strong neritic influence on the nannoplankton populations that inhabited the surface waters.

\section{Site 636}

Penetration at Site 636 was only $21 \mathrm{~m}$. The two cores taken recovered only two pieces of lithified skeletal grainstone/rudstone. Partially lithified sediment occluding some of the pore space of these pieces yielded sparse, poorly preserved nannofossils, which suggest a late Paleogene age (Section 101-636A-1W, $\mathrm{CC}$ ) and a Neogene age (Section 101-636A-2R, CC) for the fill. The age of the nannofossil-bearing, pore-filling material probably has little or no relationship to the age of the well-lithified, bank-derived clasts other than to suggest the possible timing of their emplacement into the thalweg of Northeast Providence Channel.

\section{SUMMARY AND CONCLUSIONS}

The quality of the nannofossil assemblages examined from the upper Cenozoic (Neogene and Quaternary) Leg 101 material was generally poor. Only scattered samples of relatively pure pelagic ooze contained well-preserved nannofossil assemblages (Plate 1, Figs. 1 and 2; Plate 2, Figs. 1 and 2). In general, however, most of the pelagic material was moderately to strongly diluted by shallow-water material derived from the adjacent banks (Plate 1, Figs. 3 and 4; Plate 2, Figs. 3 and 4). Diagenesis, especially in the form of calcite overgrowths, is typical of this material. This pervasive diagenetic alteration also can be traced, at least in part, to the influx of unstable carbonates (aragonite and high-magnesium calcite) from the banks. Despite the poor quality of these assemblages, usually there was enough evidence to allow biostratigraphic zonation of the sediment. A summary of these assignments for the upper Cenozoic is given in Figure 2. As illustrated in this summary figure, the late middle to late Pleistocene is represented by sediments at all sites.

Lower Pleistocene sediments apparently are present at all sites, with the exception of Site 628 . Sediment bypassing at Site 628 during the early Pleistocene would explain the presence of this unconformity. An alternative hypothesis is that this apparent unconformity may be an artifact of sediment winnowing and reworking of upper Pliocene nannofossils during the early Pleistocene. The sparse nannofossil assemblages below this apparent unconformity yield insufficient evidence to reject either hypothesis.

A significant period of nondeposition and/or erosion throughout most of the study area during the late Pliocene is evident from Table 1. In the Straits of Florida (Site 626) and on the Little Bahama Bank slope (Sites 627-630), this unconformity includes nannofossil Subzone CN12d. A similar unconformity is evident in the Exuma Sound transect, although the timing is not as consistent. At Site 632, for example, overlying Zone CN13 is apparently absent, whereas at Site 633 , the underlying nanno- 
Table 3. Nannofossil occurrences in the Albian of Hole 635B.

\begin{tabular}{|c|c|c|c|c|c|c|c|c|c|c|c|c|c|c|c|c|c|c|c|c|c|c|c|c|c|c|c|c|c|c|}
\hline $\begin{array}{c}\text { Core-section } \\
\text { (interval in } \mathrm{cm} \text { ) }\end{array}$ & $\begin{array}{l}\text { Sub-bottom } \\
\text { depth }(m)\end{array}$ & 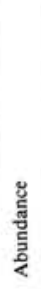 & 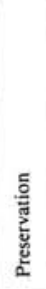 & 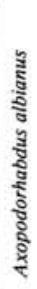 & 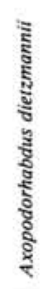 & 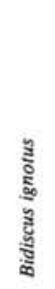 & 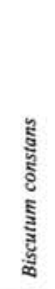 & 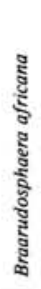 & 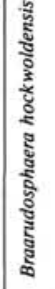 & 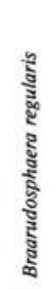 & 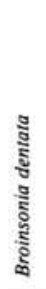 & 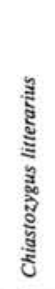 & 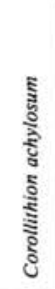 & 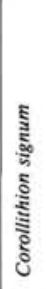 & 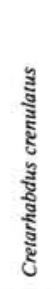 & 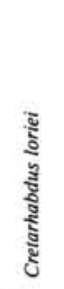 & 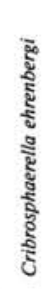 & $\begin{array}{l}\text { के } \\
\text { Eี } \\
\text { हैँ } \\
\text { है }\end{array}$ & 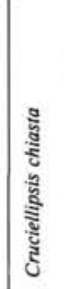 & 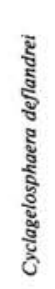 & 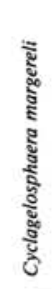 & 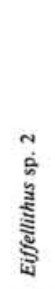 & 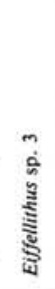 & है & 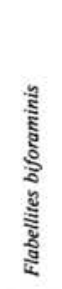 & 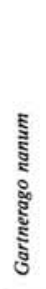 & 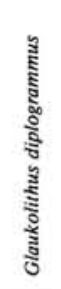 & 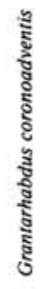 & 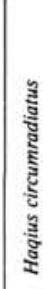 & 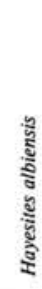 \\
\hline $\begin{array}{l}8 \mathrm{R}-1,53-54 \\
8 \mathrm{R}-1,120-121 \\
8 \mathrm{R}, \mathrm{CC} \\
9 \mathrm{R}, \mathrm{CC} \\
10 \mathrm{R}-1,40-41\end{array}$ & $\begin{array}{l}61.5 \\
62.2 \\
70.6 \\
80.2 \\
80.6\end{array}$ & $\begin{array}{l}\mathrm{C} \\
\mathrm{C} \\
\mathrm{F} \\
\mathrm{C} \\
\mathrm{C}\end{array}$ & $\begin{array}{l}\mathrm{M} \\
\mathrm{G} \\
\mathrm{M} \\
\mathrm{G} \\
\mathrm{G}\end{array}$ & $\begin{array}{l}R \\
F \\
R \\
R \\
R\end{array}$ & $\begin{array}{l}\mathbf{R} \\
\mathrm{R} \\
\mathbf{R}\end{array}$ & $\begin{array}{l}\mathrm{F} \\
\mathrm{F} \\
\mathrm{F} \\
\mathrm{F} \\
\mathrm{F}\end{array}$ & $\begin{array}{c}\mathrm{A} \\
\mathrm{A} \\
\mathrm{C} \\
\mathrm{C}-\mathrm{A} \\
\mathrm{A}\end{array}$ & R & & $\mathbf{R}$ & $\begin{array}{l}\mathbf{R} \\
\mathbf{R} \\
\mathbf{R} \\
\mathbf{R}\end{array}$ & $\begin{array}{c}F \\
F-C \\
F \\
F \\
F-C\end{array}$ & $\begin{array}{l}R \\
R \\
F \\
R \\
R\end{array}$ & $\begin{array}{l}\mathbf{R} \\
\mathrm{R}\end{array}$ & $\begin{array}{c}\mathrm{F}-\mathrm{C} \\
\mathrm{F} \\
\mathrm{F} \\
\mathrm{F} \\
\mathrm{F}\end{array}$ & $\begin{array}{c}R-F \\
R \\
R \\
R \\
F-R\end{array}$ & $\begin{array}{c}F \\
F \\
F-R \\
F \\
F\end{array}$ & $\begin{array}{l}\mathrm{R} \\
\mathrm{R} \\
\mathrm{R}\end{array}$ & & $\begin{array}{l}R \\
R \\
F\end{array}$ & & $\begin{array}{l}\text { R-F } \\
\text { R } \\
\text { R } \\
F \\
F\end{array}$ & $\begin{array}{l}\mathrm{C} \\
\mathrm{C} \\
\mathrm{C} \\
\mathrm{C} \\
\mathrm{C}\end{array}$ & $\begin{array}{c}R \\
R-F \\
R \\
R \\
R\end{array}$ & $\begin{array}{l}\mathrm{R} \\
\mathrm{R} \\
\mathrm{R} \\
\mathrm{R}\end{array}$ & $\begin{array}{l}\mathrm{R} \\
\mathrm{R} \\
\mathrm{R} \\
\mathrm{R}\end{array}$ & $\begin{array}{c}\mathrm{C} \\
\mathrm{C} \\
\mathrm{F}-\mathrm{C} \\
\mathrm{C} \\
\mathrm{F}\end{array}$ & $\begin{array}{l}\mathbf{R} \\
\mathrm{R} \\
\mathbf{R} \\
\mathrm{R} \\
\mathbf{R}\end{array}$ & $\begin{array}{l}\mathbf{R} \\
\mathrm{R} \\
\mathbf{R}\end{array}$ & \\
\hline $\begin{array}{l}10 R-2,71-72 \\
10 R, C C \\
11 R-1,86-88 \\
11 R-2,26-27 \\
11 R-3,7-8\end{array}$ & $\begin{array}{l}82.4 \\
89.6 \\
90.5 \\
91.4 \\
92.7\end{array}$ & $\begin{array}{l}\text { A } \\
\text { F } \\
\text { C } \\
\text { C } \\
\text { C }\end{array}$ & $\begin{array}{l}\mathrm{G} \\
\mathrm{M} \\
\mathrm{M} \\
\mathrm{M} \\
\mathrm{M}\end{array}$ & $\begin{array}{l}R \\
R \\
R\end{array}$ & $\begin{array}{l}\mathbf{R} \\
\mathbf{R}\end{array}$ & $\begin{array}{c}F \\
F \\
F-R \\
F \\
F\end{array}$ & $\begin{array}{l}\mathrm{C} \\
\mathrm{A} \\
\mathrm{C} \\
\mathrm{C} \\
\mathrm{C}\end{array}$ & & & & $\mathbf{R}$ & $\begin{array}{c}F \\
F \\
F \\
F-R \\
F\end{array}$ & $\mathbf{R}$ & $\mathbf{R}$ & $\begin{array}{l}\mathrm{F} \\
\mathrm{F} \\
\mathrm{F} \\
\mathrm{F} \\
\mathrm{F}\end{array}$ & $\begin{array}{l}\mathrm{R} \\
\mathrm{R} \\
\mathrm{R} \\
\mathrm{R} \\
\mathrm{R}\end{array}$ & $\begin{array}{c}\mathrm{F} \\
\mathrm{F} \\
\mathrm{F}-\mathrm{R} \\
\mathrm{F} \\
\mathrm{F}\end{array}$ & $\mathbf{R}$ & R & $\begin{array}{c}R \\
F-R \\
R ? \\
R\end{array}$ & & $\begin{array}{c}\mathrm{F} \\
\mathrm{F} \\
\mathrm{F} \\
\mathrm{F}-\mathrm{R} \\
\mathrm{C}\end{array}$ & $\begin{array}{c}\text { C } \\
\text { F } \\
\text { C } \\
\text { F-C } \\
\text { F }\end{array}$ & $\begin{array}{l}\mathrm{R} \\
\mathrm{R} \\
\mathrm{R} \\
\mathrm{R} \\
\mathrm{R}\end{array}$ & $\begin{array}{c}F \\
R \\
F \\
F-R \\
R-F\end{array}$ & R & $\begin{array}{l}\mathrm{C} \\
\mathrm{C} \\
\mathrm{C} \\
\mathrm{C} \\
\mathrm{C}\end{array}$ & $\begin{array}{l}\mathbf{R} \\
\mathbf{R} \\
\mathbf{R}\end{array}$ & $\mathbf{R}$ & \\
\hline $\begin{array}{l}11 \mathrm{R}, \mathrm{CC} \\
12 \mathrm{R}-1,109-110 \\
12 \mathrm{R}-2,70-71 \\
13 \mathrm{R}-2,77-78 \\
14 \mathrm{R}-3,100-101\end{array}$ & $\begin{array}{r}99.1 \\
100.2 \\
101.3 \\
110.6 \\
117.7\end{array}$ & $\begin{array}{l}\text { C } \\
\text { C } \\
\text { A } \\
\text { C } \\
\text { C }\end{array}$ & $\begin{array}{l}\mathrm{M} \\
\mathrm{M} \\
\mathrm{G} \\
\mathrm{M} \\
\mathrm{G}\end{array}$ & $\begin{array}{l}R \\
R \\
R \\
R\end{array}$ & $\mathbf{R}$ & $\begin{array}{c}R \\
F-R \\
R \\
F\end{array}$ & $\begin{array}{c}\text { A } \\
\text { C } \\
\text { C-F } \\
\text { C } \\
\text { C }\end{array}$ & $\mathbf{F}$ & $\begin{array}{l}\mathbf{R} \\
\mathbf{R}\end{array}$ & $\begin{array}{c}R \\
F-R\end{array}$ & & $\begin{array}{c}\mathrm{F}-\mathrm{C} \\
\mathrm{F} \\
\mathrm{R} \\
\mathrm{R}\end{array}$ & $\begin{array}{l}\mathrm{R} \\
\mathrm{R} \\
\mathrm{R}\end{array}$ & $\mathbf{R}$ & $\begin{array}{l}\mathrm{C} \\
\mathrm{F} \\
\mathrm{F} \\
\mathrm{F} \\
\mathrm{R}\end{array}$ & $\begin{array}{l}\mathrm{R} \\
\mathrm{R} \\
\mathrm{R} \\
\mathrm{R}\end{array}$ & $\begin{array}{c}\text { R-F } \\
\text { F }\end{array}$ & $\mathbf{R}$ & $\begin{array}{c}\mathrm{R} \\
\mathrm{F}-\mathrm{R} \\
\mathrm{R}\end{array}$ & $\begin{array}{c}\mathrm{F} \\
\mathrm{F}-\mathrm{R} \\
\mathrm{R}\end{array}$ & $\mathbf{R}$ & $\begin{array}{l}\mathrm{F} \\
\mathrm{F} \\
\mathrm{F}\end{array}$ & $\begin{array}{l}\mathrm{C} \\
\mathrm{F} \\
\mathrm{F}\end{array}$ & $\begin{array}{l}\mathbf{R} \\
\mathbf{R} \\
\mathbf{R}\end{array}$ & $\begin{array}{l}\mathrm{F} \\
\mathrm{R} \\
\mathrm{R} \\
\mathrm{R} \\
\mathrm{F}\end{array}$ & & $\begin{array}{c}C-A \\
C \\
F-C \\
F \\
F\end{array}$ & $\begin{array}{l}\mathbf{R} \\
\mathbf{R}\end{array}$ & $\mathbf{R}$ & $\begin{array}{l}\mathbf{R} \\
\mathbf{R}\end{array}$ \\
\hline $\begin{array}{l}14 \mathrm{R}-3,148-149 \\
14 \mathrm{R}, \mathrm{CC}\end{array}$ & $\begin{array}{l}118.2 \\
117.7\end{array}$ & $\begin{array}{l}\text { C } \\
\text { A }\end{array}$ & $\begin{array}{l}G \\
G\end{array}$ & & & $F$ & $\begin{array}{l}\text { C } \\
\text { A }\end{array}$ & $\begin{array}{l}\mathrm{R} \\
\mathrm{R}\end{array}$ & $\begin{array}{c}F-R \\
R\end{array}$ & & & $\underset{F}{F-R}$ & $\stackrel{R}{F-R}$ & & $\begin{array}{l}R \\
F\end{array}$ & $R-F$ & $F$ & & $\begin{array}{l}\mathrm{R} \\
\mathrm{F}\end{array}$ & $\begin{array}{l}R \\
F\end{array}$ & $\begin{array}{l}\mathrm{F}-\mathrm{R} \\
\mathrm{F}-\mathrm{R}\end{array}$ & & & $\begin{array}{l}\mathrm{R} \\
\mathrm{F}\end{array}$ & $\begin{array}{l}R \\
F\end{array}$ & & $\begin{array}{l}\mathrm{F} \\
\mathrm{C}\end{array}$ & $R$ & & \\
\hline
\end{tabular}

Note: Preservation: $\mathrm{P}=$ poor, $\mathrm{G}=$ good, $\mathrm{M}=$ moderate. Occurrence: $\mathrm{R}=$ rare, $\mathrm{F}=$ few, $\mathrm{C}=$ common, $\mathrm{A}=$ abundant.

fossil subzones $(\mathrm{CN} 12 \mathrm{a}-\mathrm{c})$ are absent but $\mathrm{CN} 12 \mathrm{~d}$ is represented. Regardless of the exact timing, it is clear that the late Pliocene was a time of a significantly higher probability of nondeposition and/or erosion in the deep waters of the northern Bahamas. This may be related to the significant sea-level fluctuations inherent in the onset of northern hemisphere glaciation during this time. For example, the sea-level drop at the base of Cycle 3.8, Supercycle TB3 of Haq et al. (1987), may have cut off the supply of bank-derived material while serving to intensify bottom-current activity around the bank, thus promoting the formation of unconformities.

The late Miocene and early Pliocene are much better represented in the rock record drilled by ODP Leg 101. Scattered samples dominated by pelagic components (Plate 2, Figs. 1 and 2) allow biostratigraphic control to be established, although the biostratigraphic resolution is often limited by poor nannofossil preservation and assemblages that are highly diluted by bankderived debris (Plate 2, Figs. 3 and 4). It appears that net sedimentation occurred at all sites during the $\mathrm{CN} 9$ and $\mathrm{CN} 10$ chronozones. At several of the sites, the relatively thick accumulation of upper Miocene and lower Pliocene sediments attests to high rates of sediment accumulation. This trend is especially notable along the Exuma Sound transect, where upper Miocene and/or lower Pliocene periplatform ooze and calciturbidites accumulated at rates of over $100 \mathrm{~m} / \mathrm{m}$.y. (Austin, Schlager, et al., $1986)$. Only four sites $(626,627,628$, and 635$)$ penetrated sediments below the upper Miocene. No middle or lower Miocene sediments were recovered at Site 635 , and only two cores $(\approx 19 \mathrm{~m})$ of middle Miocene sediment were recovered from Site 628 . The limited biostratigraphic evidence available from Sites 626 and 627 suggests that sediment accumulation and preservation were episodic during the early and middle Miocene.

No pre-Neogene sediments were penetrated in Exuma Sound. Obviously redeposited Paleogene nannofossils occur in core material from Sites 635 and 636, but these have no real biostratigraphic significance other than to indicate the age of the source for some of the redeposited material. Hole 634A penetrated a minimum of $28 \mathrm{~m}$ of lower Eocene chalk and chert, but the overlying Paleogene was washed during drilling. Hole 626D penetrated a minimum of $57 \mathrm{~m}$ of uppermost Oligocene sediment, but core recovery was so low that only small core-catcher samples were available for study. In essence, recovery of a significantly detailed Paleogene record by Leg 101 drilling is limited to two sites (627 and 628). At Site 627, a thin interval (Core 101627B-20X) of uppermost Oligocene chalk was penetrated, but the exact thickness of this unit is unknown owing to core disruption caused by the penetration of underlying middle Eocene cherts. In addition, it is impossible to say whether any other upper Eocene or lower Oligocene sediments are present at this site. Approximately $60 \mathrm{~m}$ of upper Paleocene to middle Eocene chalks and cherts was penetrated in Hole 627B, but core recovery was poor. As a result, little can be reliably stated as to the stratigraphic continuity of this sequence. The only well-recovered, intact Paleogene section drilled on ODP Leg 101 was from Site 628. At this site, Hole 628A penetrated approximately 134 $\mathrm{m}$ of lowermost to upper (but not uppermost) Oligocene oozes and chalks. This relatively complete and continuous section indicates that pelagic conditions existed over the area for almost the entire Oligocene. This is in contrast to the record that is suggested by the sections at Site 627. At present, it is impossible to ascertain whether the long, relatively complete record at Site 628 or the abbreviated record at Site 627 is more typical for the northern Bahamas. The Oligocene at Site 628 is underlain by a minimum of $20 \mathrm{~m}$ of lower to middle Eocene chalk and chert. These lower to middle Eocene cherty intervals (also evident at Sites 627 and 634) correlate with the widespread Horizon $\mathrm{A}^{\mathrm{c}}$ cherts and reflect increased siliceous biogenic activity everywhere in the western North Atlantic during this time.

Aside from exotic clasts of Cretaceous material deposited as channel fill in Northeast Providence channel, the Cretaceous record was penetrated at two sites (627 and 634). The record at Site 634 seems to span the entire Campanian. However, core recovery was poor, and much of the material retrieved was platform-derived limestone. The nature of the material recovered, the results from downhole measurements, and the better documentation available from DSDP Site 98 indicate that the Campanian in this area consists of interbedded pelagic chalks and sediment gravity-flow deposits with platform-derived material. Core recovery was better for the Campanian sequence at Site 627 . A minimum of $76 \mathrm{~m}$ of upper Campanian chalks was pene- 


\begin{tabular}{|c|c|c|c|c|c|c|c|c|c|c|c|c|c|c|c|c|c|c|c|c|c|c|c|c|c|c|c|c|c|c|c|c|c|}
\hline 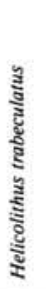 & 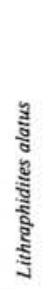 & 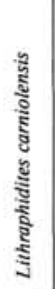 & 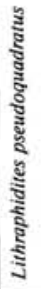 & 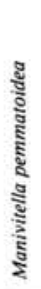 & 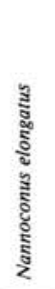 & 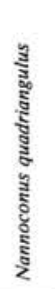 & 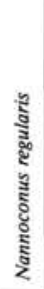 & 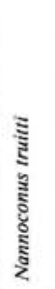 & 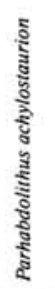 & 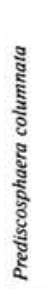 & 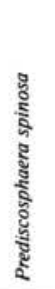 & 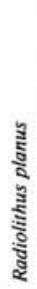 & 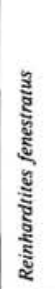 & 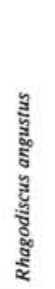 & 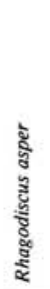 & 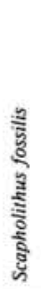 & 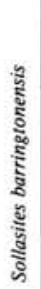 & 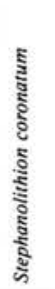 & 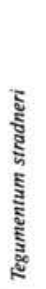 &  & 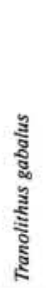 & 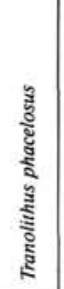 & 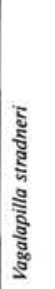 & 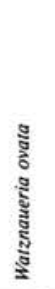 & 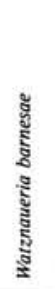 & 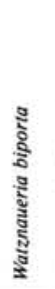 & 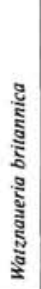 & 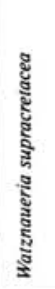 & 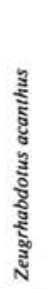 & 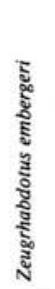 & 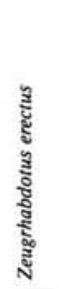 & 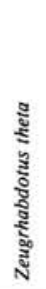 & 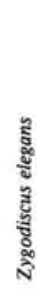 \\
\hline $\begin{array}{c}\mathrm{F}-\mathrm{R} \\
\mathrm{R} \\
\mathrm{F} \\
\mathrm{R}\end{array}$ & $\begin{array}{c}\mathrm{R} \\
\mathrm{C}-\mathrm{A} \\
\mathrm{R}\end{array}$ & $\begin{array}{c}\mathrm{C} \\
\mathrm{F} \\
\mathrm{C} \\
\mathrm{C}-\mathrm{A} \\
\mathrm{C}\end{array}$ & & $\begin{array}{l}\mathrm{F} \\
\mathrm{F} \\
\mathrm{F}\end{array}$ & $R$ & & & $\begin{array}{c}R \\
R \\
F-R \\
R \\
F\end{array}$ & $\begin{array}{c}\mathrm{C}-\mathrm{F} \\
\mathrm{C}-\mathrm{F} \\
\mathrm{C} \\
\mathrm{C} \\
\mathrm{C}\end{array}$ & $\begin{array}{c}\mathrm{C} \\
\mathrm{C} \\
\mathrm{F} \\
\mathrm{F}-\mathrm{C} \\
\mathrm{F}\end{array}$ & $\begin{array}{c}? \\
\text { R-F } \\
R \\
R \\
R\end{array}$ & & $\begin{array}{c}F \\
\text { F } \\
R-F \\
R-F \\
F-R \\
F\end{array}$ & $\begin{array}{l}F \\
F \\
R \\
F \\
R\end{array}$ & $\begin{array}{l}\mathrm{R} \\
\mathrm{R} \\
\mathrm{R} \\
\mathrm{R} \\
\mathrm{R}\end{array}$ & $\begin{array}{l}\mathbf{R} \\
\mathbf{R} \\
\mathbf{R} \\
\mathrm{R} \\
\mathbf{R}\end{array}$ & $\begin{array}{l}\mathbf{R} \\
\mathbf{R} \\
\mathbf{R} \\
\mathrm{R} \\
\mathrm{R}\end{array}$ & $\begin{array}{c}R \\
F-R \\
R \\
R \\
R\end{array}$ & $\begin{array}{l}\mathrm{R} \\
\mathrm{R} \\
\mathrm{R}\end{array}$ & $\begin{array}{l}\mathrm{R} \\
\mathrm{R} \\
\mathrm{R} \\
\mathrm{R}\end{array}$ & $\begin{array}{l}\mathrm{R} \\
\mathrm{R} \\
\mathrm{R} \\
\mathrm{R}\end{array}$ & $\begin{array}{c}F \\
F-R \\
R \\
R-F \\
F\end{array}$ & $\begin{array}{c}R \\
F \\
R \\
F \\
R-F\end{array}$ & $\begin{array}{l}\mathbf{R} \\
\mathbf{R} \\
\mathbf{R} \\
\mathrm{R}\end{array}$ & $\begin{array}{c}\mathrm{A} \\
\mathrm{A} \\
\mathrm{C}-\mathrm{A} \\
\mathrm{A} \\
\mathrm{A}-\mathrm{C}\end{array}$ & $\begin{array}{l}\mathbf{F} \\
\mathbf{F} \\
\mathbf{F} \\
\mathbf{F} \\
\mathbf{F}\end{array}$ & & $\begin{array}{c}\text { R-F } \\
\text { R-F } \\
F \\
F \\
F-R\end{array}$ & $\begin{array}{c}\mathbf{R} \\
\mathrm{F} \\
\mathrm{R} \\
\mathrm{C}-\mathrm{F} \\
\mathrm{R}\end{array}$ & $\begin{array}{c}R \\
R-F \\
R \\
R \\
F-R\end{array}$ & $\begin{array}{c}\mathrm{A} \\
\mathrm{A} \\
\mathrm{C}-\mathrm{F} \\
\mathrm{A} \\
\mathrm{A}\end{array}$ & $\mathbf{R}$ & $\begin{array}{l}R \\
F\end{array}$ \\
\hline$R$ & $\mathbf{R}$ & $\begin{array}{l}\mathrm{C} \\
\mathrm{C} \\
\mathrm{C} \\
\mathrm{C} \\
\mathrm{C}\end{array}$ & & $\begin{array}{l}F \\
F \\
F \\
F \\
F\end{array}$ & R & & & $\begin{array}{l}\mathrm{R} \\
\mathrm{F}\end{array}$ & $\begin{array}{l}\text { C } \\
C \\
C \\
\text { F } \\
F\end{array}$ & $\begin{array}{l}\mathrm{C} \\
\mathrm{F} \\
\mathrm{F} \\
\mathrm{F} \\
\mathrm{F}\end{array}$ & $\begin{array}{l}\mathbf{R} \\
\mathbf{R} \\
\mathbf{R} \\
\mathbf{R} \\
\mathrm{R}\end{array}$ & $\mathbf{R}$ & $\begin{array}{l}\mathrm{F} \\
\mathrm{R} \\
\mathrm{R} \\
\mathrm{R} \\
\mathrm{R}\end{array}$ & $\begin{array}{c}F \\
F \\
R-F \\
R-F \\
R\end{array}$ & $\begin{array}{l}\mathrm{F} \\
\mathrm{R} \\
\mathrm{F} \\
\mathrm{F} \\
\mathrm{R}\end{array}$ & & $\begin{array}{l}\mathrm{R} \\
\mathrm{R}\end{array}$ & R & $\mathbf{R}$ & $\begin{array}{l}\mathrm{R} \\
\mathrm{R} \\
\mathrm{R}\end{array}$ & R & $\begin{array}{c}R \\
R-F \\
R \\
F \\
R\end{array}$ & $\begin{array}{l}\mathrm{F} \\
\mathrm{R} \\
\mathrm{R} \\
\mathrm{F}\end{array}$ & $\begin{array}{c}F \\
R \\
R \\
F-R \\
R\end{array}$ & $\begin{array}{l}\text { C } \\
\text { A } \\
\text { C } \\
\text { C } \\
\text { C }\end{array}$ & $\begin{array}{l}\mathrm{F} \\
\mathrm{F} \\
\mathrm{F} \\
\mathrm{F} \\
\mathrm{R}\end{array}$ & $R$ & $\begin{array}{l}F \\
F \\
R \\
F \\
R\end{array}$ & $\begin{array}{c}\mathrm{F} \\
\mathrm{R} \\
\mathrm{F} \\
\mathrm{F}-\mathrm{C} \\
\mathrm{F}\end{array}$ & $\begin{array}{c}R-F \\
F \\
R \\
F-R \\
R-F\end{array}$ & $\begin{array}{l}\text { C } \\
\text { A } \\
\text { C } \\
\text { C } \\
\text { C }\end{array}$ & $\begin{array}{l}\mathrm{R} \\
\mathrm{R} \\
\mathrm{R}\end{array}$ & $F$ \\
\hline $\begin{array}{l}\mathrm{R} \\
\mathrm{R}\end{array}$ & $\mathbf{R}$ & $\begin{array}{l}A \\
C \\
C \\
C \\
F\end{array}$ & & $\begin{array}{l}F \\
F \\
F \\
F \\
R\end{array}$ & $\begin{array}{c}R \\
F \\
F-C\end{array}$ & $\begin{array}{l}R \\
F\end{array}$ & $\mathrm{~F}$ & $\begin{array}{c}\mathrm{F} \\
\mathrm{F} \\
\mathrm{C}-\mathrm{F} \\
\mathrm{C}-\mathrm{F} \\
\mathrm{C}\end{array}$ & $\begin{array}{l}\mathrm{C} \\
\mathrm{F} \\
\mathrm{F} \\
\mathrm{F}\end{array}$ & $\begin{array}{c}\mathrm{F} \\
\mathrm{F} \\
\mathrm{F}-\mathrm{C} \\
\mathrm{C}-\mathrm{F}\end{array}$ & $\begin{array}{c}\mathbf{R} \\
\mathbf{R} \\
\mathrm{F}-\mathrm{R}\end{array}$ & $\begin{array}{l}R \\
R\end{array}$ & $\begin{array}{c}\mathrm{F} \\
\mathrm{F} \\
\mathrm{R} \\
\mathrm{R}-\mathrm{F} \\
\mathrm{R}\end{array}$ & $\begin{array}{l}\mathrm{F} \\
\mathrm{R} \\
\mathrm{F} \\
\mathrm{R} \\
\mathrm{F}\end{array}$ & $\begin{array}{l}\mathrm{R} \\
\mathrm{F} \\
\mathrm{R} \\
\mathrm{R} \\
\mathrm{F}\end{array}$ & $\begin{array}{l}\mathrm{R} \\
\mathrm{R} \\
\mathrm{R}\end{array}$ & $\mathbf{R}$ & $\begin{array}{l}\mathrm{R} \\
\mathrm{F}\end{array}$ & $\mathrm{R}$ & R & $R$ & $\begin{array}{c}\mathrm{F} \\
\mathrm{R} \\
\mathrm{R}-\mathrm{F}\end{array}$ & $\begin{array}{c}\text { R-F } \\
F \\
F \\
F \\
R\end{array}$ & $\begin{array}{l}\mathbf{R} \\
\mathrm{R} \\
\mathrm{R}\end{array}$ & $\begin{array}{l}\text { A } \\
\text { C } \\
\text { C } \\
\text { C } \\
\text { C }\end{array}$ & $\begin{array}{c}C \\
F-R \\
R-F \\
F \\
R\end{array}$ & R & $\begin{array}{l}\mathrm{F} \\
\mathrm{R} \\
\mathrm{R} \\
\mathrm{R} \\
\mathrm{R}\end{array}$ & $\begin{array}{c}F \\
R \\
R-F \\
F-R\end{array}$ & $\begin{array}{c}F \\
R \\
F-R \\
F\end{array}$ & $\begin{array}{l}\text { A } \\
\text { C } \\
\text { C } \\
\text { C } \\
\text { C }\end{array}$ & & $\begin{array}{l}F \\
R\end{array}$ \\
\hline & & $\begin{array}{l}\mathrm{F} \\
\mathrm{A}\end{array}$ & R & $\begin{array}{l}F \\
F\end{array}$ & & $\begin{array}{c}\mathrm{F}-\mathrm{R} \\
\mathrm{R} ?\end{array}$ & R & $\begin{array}{l}\mathrm{C} \\
\mathrm{F}\end{array}$ & $\begin{array}{c}\mathrm{F}-\mathrm{R} \\
\mathrm{C}\end{array}$ & $\begin{array}{l}F \\
F\end{array}$ & R & $\begin{array}{l}\mathrm{R} \\
\mathrm{R}\end{array}$ & $\begin{array}{l}R \\
F\end{array}$ & $\begin{array}{l}F \\
F\end{array}$ & $\begin{array}{c}R \\
F-R\end{array}$ & $\begin{array}{l}\mathbf{R} \\
\mathrm{R}\end{array}$ & & $\begin{array}{l}\mathrm{R} \\
\mathrm{R}\end{array}$ & & & & & $\begin{array}{l}\mathrm{F} \\
\mathrm{F}\end{array}$ & $\mathbf{F}$ & $\begin{array}{l}\text { C } \\
\text { A }\end{array}$ & $\begin{array}{l}\mathrm{F} \\
\mathrm{F}\end{array}$ & R & $\begin{array}{l}\mathbf{R} \\
\mathbf{R}\end{array}$ & F-R & $\begin{array}{l}\mathbf{R} \\
\mathbf{R}\end{array}$ & $\begin{array}{l}\text { C } \\
\text { A }\end{array}$ & & \\
\hline
\end{tabular}

trated at this site. This sequence is totally pelagic in character (Plate 3, Figs. 1 and 2), suggesting that normal open-marine conditions existed over an oceanic platform at this site during the late Campanian.

One of the more controversial results of Leg 101 was the Upper Cretaceous, post-drowning sequence at Little Bahama Bank (Site 627) and its relationship to the basinal, Lower Cretaceous sequence in Northeast Providence Channel (Site 635). The hemipelagic marly chalks and limestones of Hole 627B are clearly Cenomanian. The top of this sequence contains nannofossils (and planktonic foraminifers), which place it solidly within the lower middle Cenomanian. There is a regular biostratigraphic progression downhole, with the base of the sequence containing nannofossils (and planktonic foraminifers), which indicate the lowest Cenomanian to uppermost Albian (at or slightly below the Albian/Cenomanian boundary). Larger foraminifers and palynomorphs from the underlying platform carbonates indicate that they are uppermost Albian (Vraconian; Austin, Schlager, et al., 1986). This biostratigraphic relationship indicates that little or no time elapsed between drowning of the platform in the latest Albian and the commencement of hemipelagic sedimentation in the earliest Cenomanian.

The drowning event at Little Bahama Bank is clearly not isochronous with the postulated drowning event in Northeast Providence Channel, as represented in Hole 635B. While a platform was thriving at Little Bahama Bank, organic-rich marly limestones were being deposited in Northeast Providence Channel. Deposition of these marly limestones at Site 635 occurred from at least the early middle Albian through the late (but not latest) Albian. No clear evidence of shallow-water conditions is visible within the upper Albian portion of this unit. The nannofossil assemblages are clearly oceanic in character. In addition, the benthic-foraminiferal assemblages indicate bathyal depths (Austin, Schlager, et al., 1986). The only suggestion of deposition under the influence of neritic conditions occurs at the base of the unit (upper lower to lower middle Albian), where common nannoconids characterize the nannofossil assemblages. This is not unexpected, however, considering the proximity of this site to the continental margin. It is clear from this evidence that a deep-water channel at Site 635 was already well established by (at least) the earliest middle Albian.

\section{ACKNOWLEDGMENTS AND RESPONSIBILITIES}

Analysis of the nannofossil assemblages and compilation of the biostratigraphy for these ODP sites were divided between the authors. Verbeek was responsible for analysis of material from Sites 626 and 627 . All other sites were analyzed by Watkins. Both contributed to the writing, with Watkins responsible for any errors appearing in the final manuscript. We are indebted to the Director of the Geological Survey of the Netherlands for granting permission for Verbeek to participate in Leg 101. Financial support was graciously supplied to the authors by the Netherlands Organization for the Advancement of Pure Research (ZWO), USSAC-JOI, and the Department of Geology, University of Nebraska. We also thank Michael J. Moran, Theresa M. Dunn, and Niko Wijker for their assistance in sample preparation. Comments by J. A. Austin, Jr., and reviews by W. G. Siesser and W. W. Hay significantly improved the manuscript and are greatly appreciated.

\section{REFERENCES}

Austin, J. A., Schlager, W., et al., 1986. Proc. ODP, Init. Repts., 101: College Station, TX (Ocean Drilling Program).

Berggren, W. A., Kent, D. V., and Flynn, J. J., 1985a. Jurassic to Paleogene: Part 2. Paleogene geochronology and chronostratigraphy. In Snelling, N. J. (Ed.), The Chronology of the Geological Record. Geol. Soc. London Mem., 10:141-195.

Berggren, W. A., Kent, D. V., and Van Couvering, J. A., 1985b. The Neogene: Part 2, Neogene geochronology and chronostratigraphy. In Snelling, N. J. (Ed.), The Chronology of the Geological Record. Geol. Soc. London Mem., 10:211-259.

Bolli, H. M., Saunders, J. B., and Perch-Nielsen, K., 1985. Plankton Stratigraphy: Cambridge (Cambridge Univ. Press).

Bukry, D., 1973. Low-latitude coccolith biostratigraphic zonation. In Edgar, N. T., Saunders, J. B., et al., Init. Repts. DSDP, 15: Washington (U.S. Govt. Printing Office), 685-703.

1975. Coccolith and silicoflagellate stratigraphy, northwestern Pacific Ocean, Deep Sea Drilling Project Leg 32. In Larson, R. L., Moberly, R., et al., Init. Repts. DSDP, 32: Washington (U.S. Govt. Printing Office), 677-701.

, 1981. Pacific coast coccolith stratigraphy between Point Conception and Cabo Corrientes, Deep Sea Drilling Project Leg 63. In Yeats, R. S., Haq, B. U., et al., Init. Repts. DSDP, 63: Washington (U.S. Govt. Printing Office), 445-471.

Crux, J. A., 1982. Upper Cretaceous (Cenomanian to Campanian) calcareous nannofossils. In Lord, A. R. (Ed.), A Stratigraphic Index of Calcareous Nannofossils: Chichester (Ellis Horwood, Ltd.), 81-135.

Ericson, D. B., and Wollin, G., 1968. Pleistocene climate and chronology in deep-sea sediments. Science, 162:1227-1234. 
Gartner, S., Jr., 1977. Calcareous nannofossil biostratigraphy and revised zonation of the Pleistocene. Mar. Micropaleontol., 2:1-25.

Haq, B. U., Hardenbol, J., and Vail, P. R., 1987. Chronology of fluctuating sea levels since the Triassic ( 250 million years ago to present). Science, 235:1156-1167.

Hollister, C. D., Ewing, J. I., et al., 1972. Init. Repts. DSDP, 11: Washington (U.S. Govt. Printing Office).

Manivit, H., Perch-Nielsen, K., Prins, B., and Verbeek, J. W., 1977. Mid Cretaceous calcareous nannofossil biostratigraphy. $K$. Ned. Akad. Wet. Proc., B80:169-181.

Okada, H., and Bukry, D., 1980. Supplementary modification and introduction of code numbers to the low-latitude coccolith biostratigraphic zonation (Bukry, 1973, 1975). Mar. Micropaleontol., 5:321325 .

Perch-Nielsen, K., 1979. Calcareous nannofossils from the Cretaceous between the North Sea and the Mediterranean. In Wiedmann, J. (Ed.), Aspekte der Kreide Europas: Int. Union Geol. Sci., Ser. A: 223-272.
1985. Mesozoic calcareous nannofossils. In Bolli, H. M. Saunders, J. B., and Perch-Nielsen, K., Plankton Stratigraphy: Cambridge (Cambridge Univ. Press), 329-426.

Sissingh, W., 1977. Biostratigraphy of Cretaceous calcareous nannoplankton. Geol. Mijnbouw, 57:433-440.

Thierstein, H. R., Geitzenauer, K. R., Molfino, B., and Shackleton, N. J., 1977. Global synchroneity of late Quaternary coccolith datum levels: Validation by oxygen isotopes. Geology, 5:400-404.

van Hinte, J. E., 1976. A Cretaceous time scale. AAPG Bull., 60:498516.

Watkins, D. K., and Bowdler, J. L., 1984. Cretaceous calcareous nannofossils from Deep Sea Drilling Project Leg 77, southeast Gulf of Mexico. In Buffler, R. T., Schlager, W., et al., Init. Repts. DSDP, 77: Washington (U.S. Govt. Printing Office), 649-674.

Date of initial receipt: 5 January 1987

Date of acceptance: 12 June 1987

Ms 101B-131 


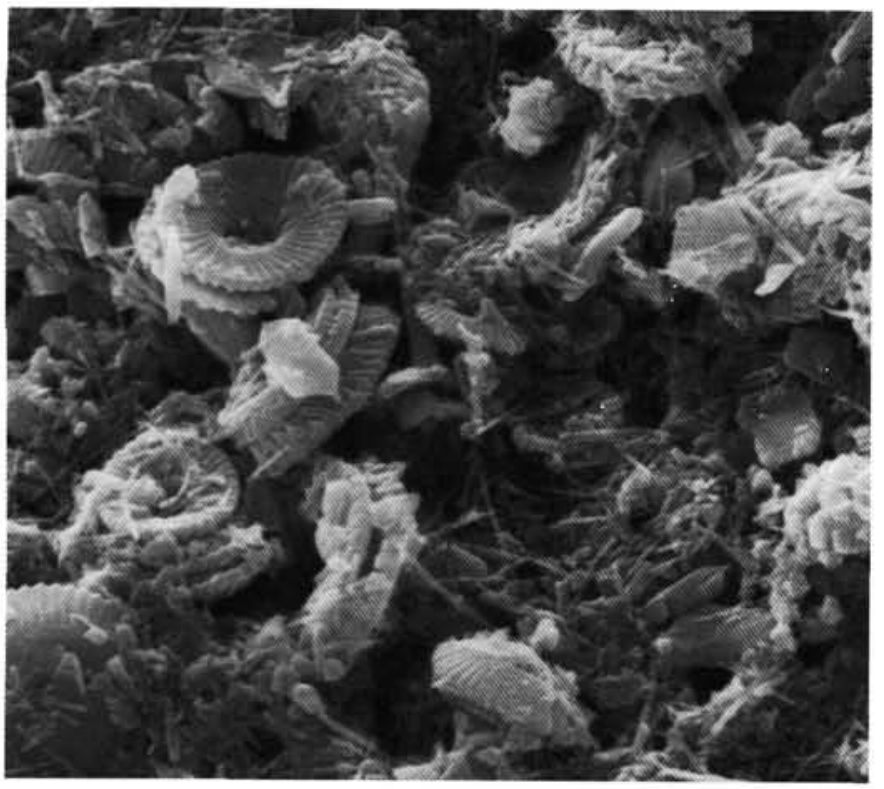

1

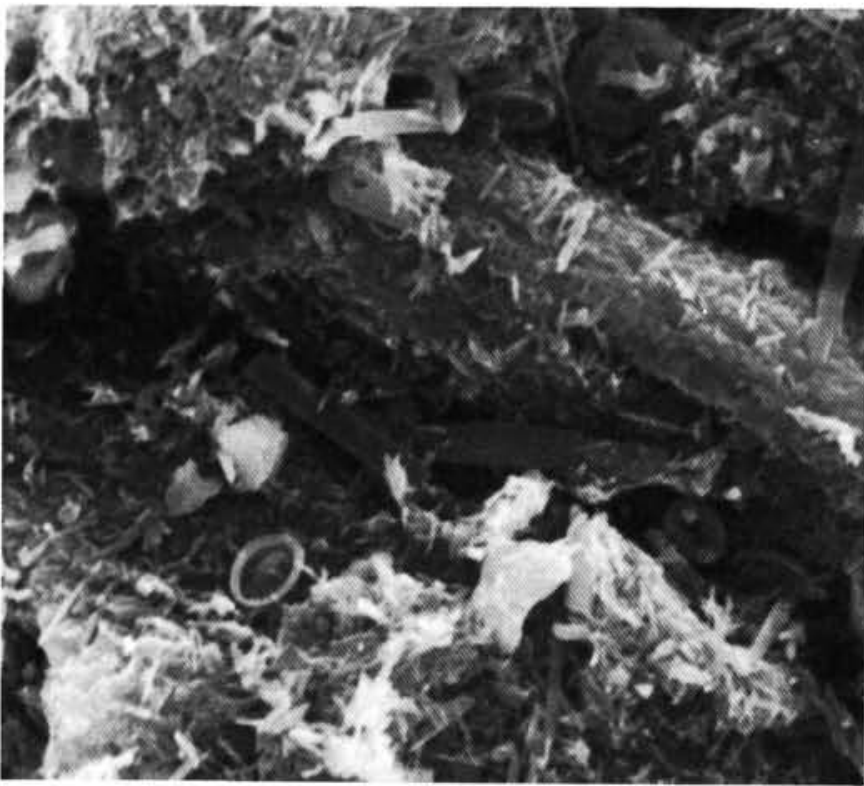

3

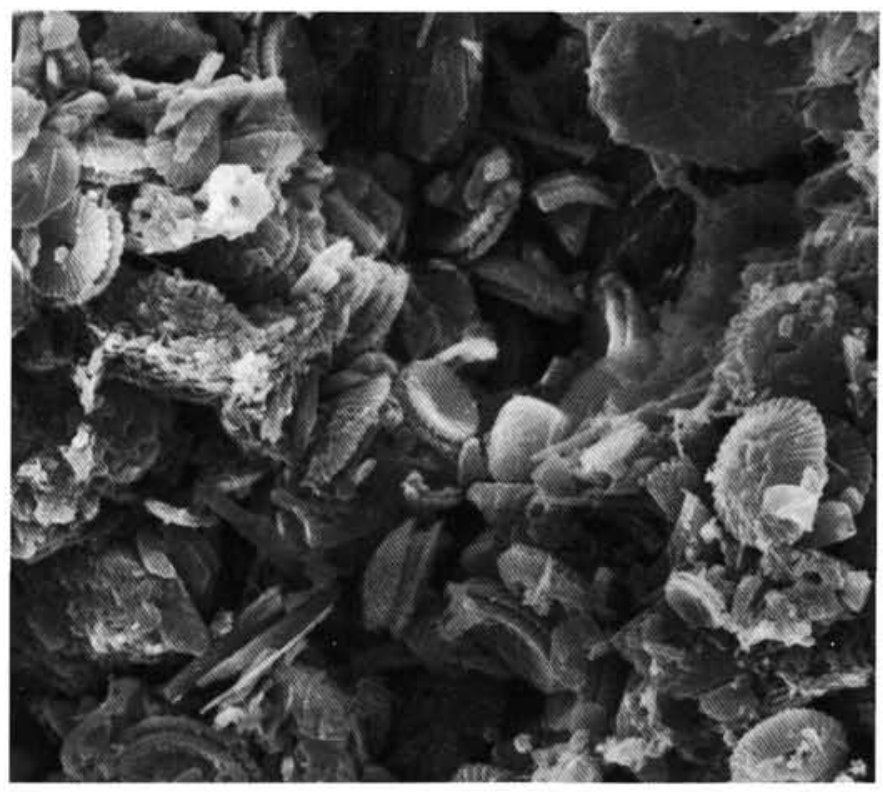

2

$5 \mu \mathrm{m}$

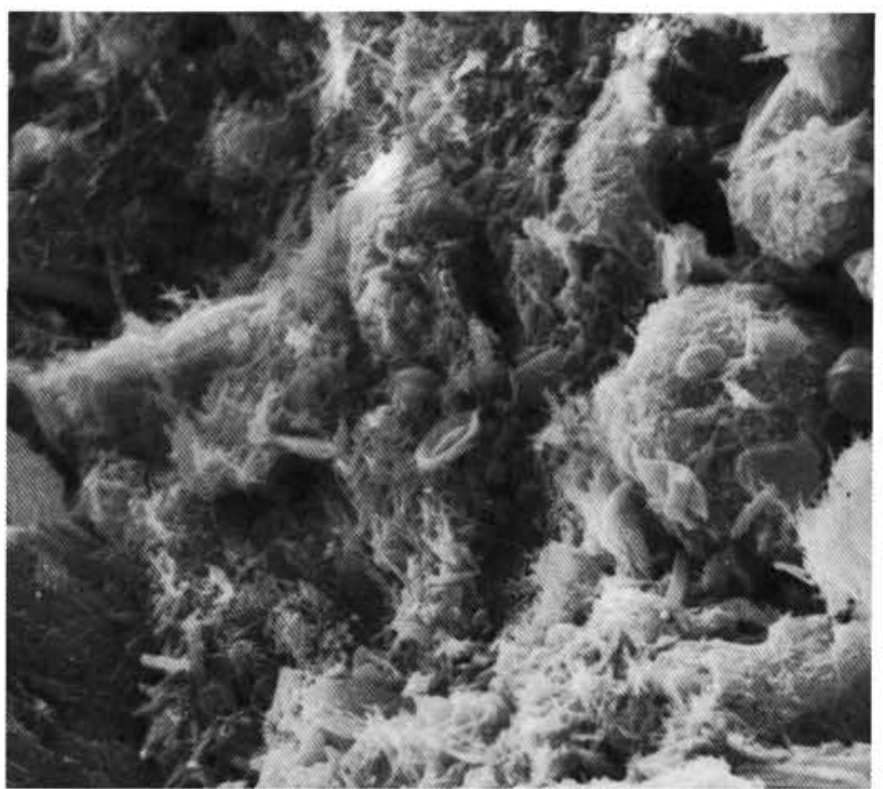

4

$5 \mu \mathrm{m}$

Plate 1. 1 and 2. Sample 101-631A-1 H-1, $80-81 \mathrm{~cm}$, illustrating the overwhelming contribution of platform-derived debris dominated by aragonite needles. Coccoliths occur as isolated elements. This type of sediment characterizes much of the Quaternary interglacial record from Leg 101. 3. Sample 101-631A-1H-3, 80-81 cm, illustrating coccolith-rich sediment having a lesser platform-derived contribution. Most of the sediment is best illustrated here, although isolated patches of sediment with higher needle component occur, as is illustrated in 4 . This type of sediment is typical of that deposited during Quaternary glacial periods. 


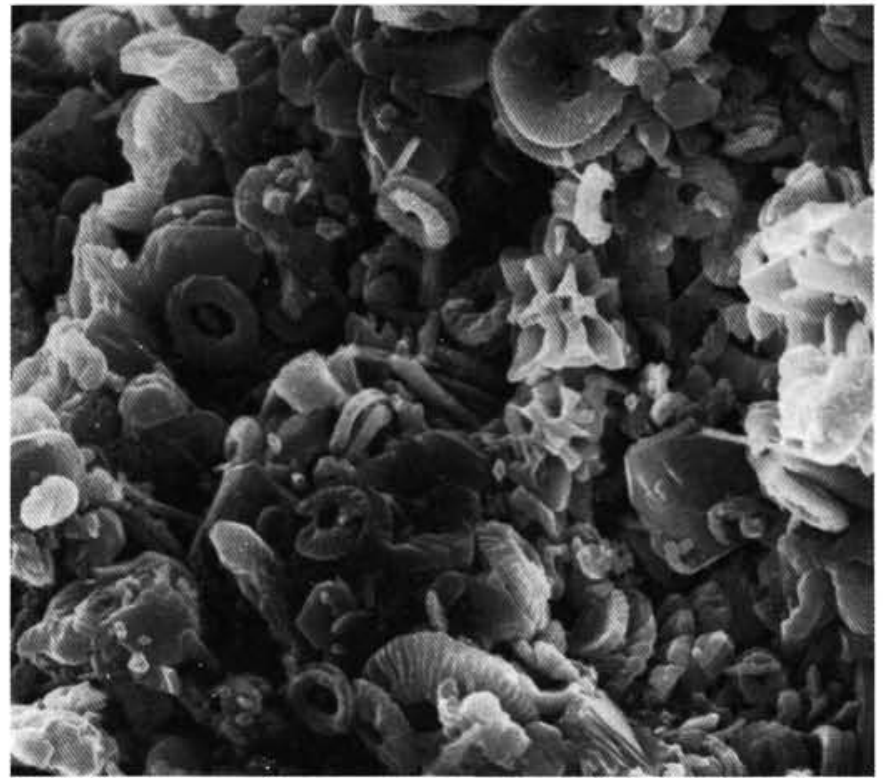

1

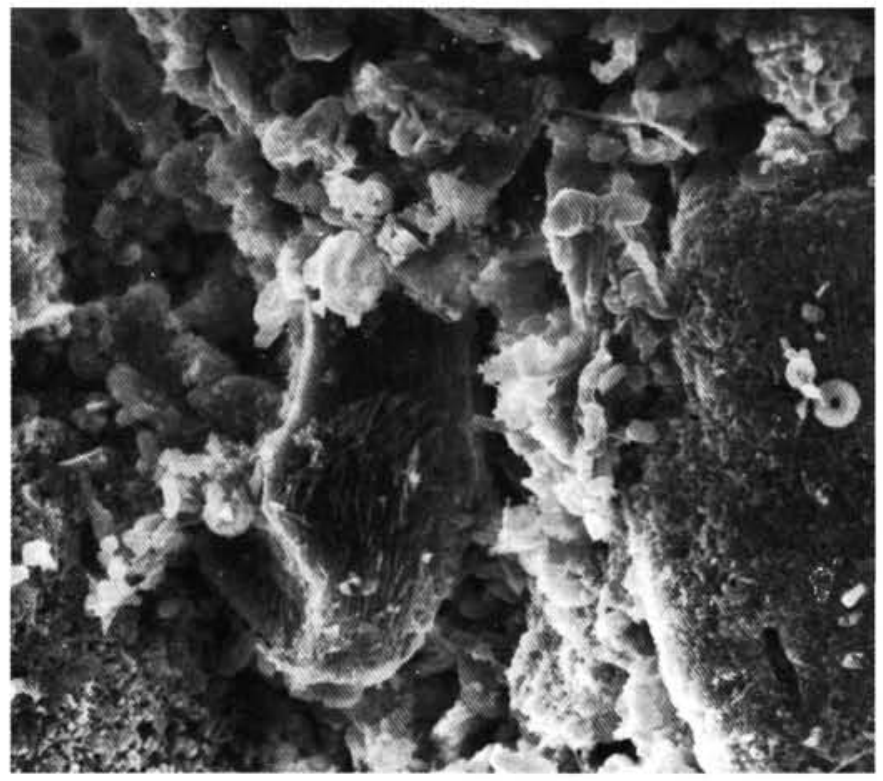

3

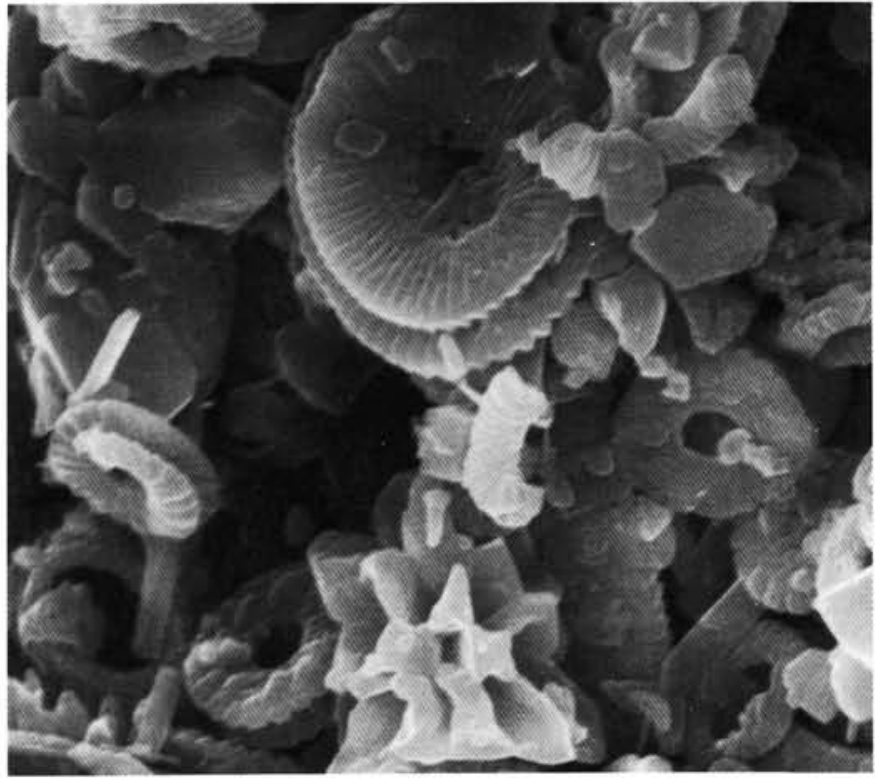

2

$\overline{1 \mu \mathrm{m}}$

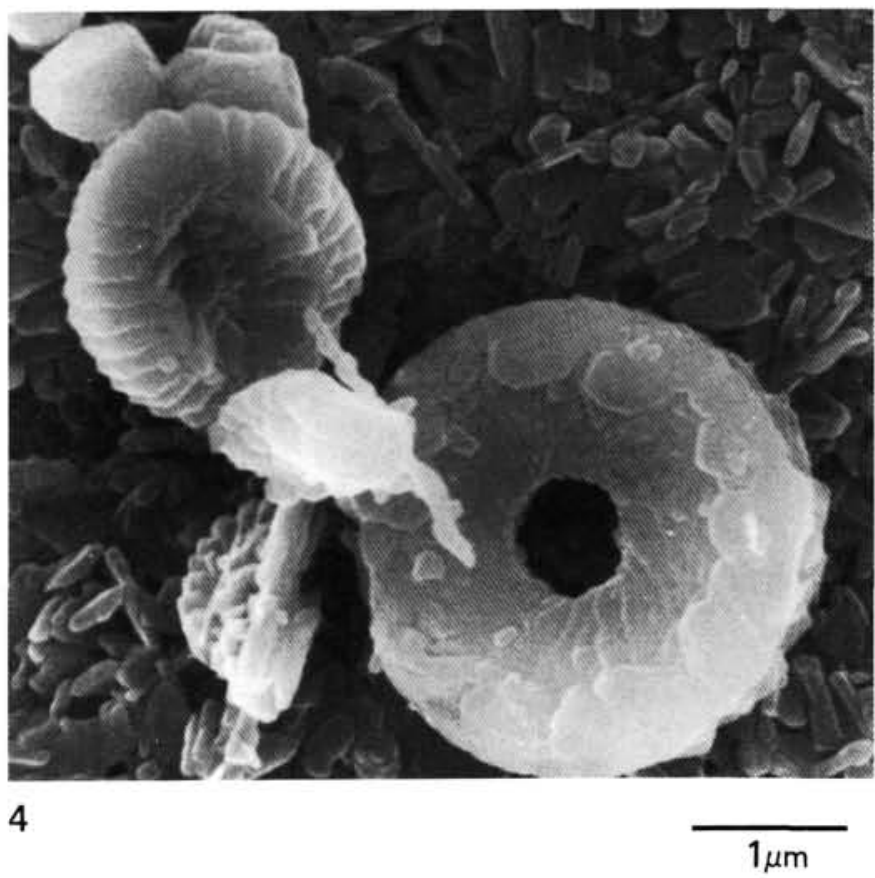

Plate 2. 1 and 2. Sample 101-633A-16X-1, 80-81 cm. Lower Pliocene chalk. The original dominance of pelagic carbonate over platform-derived material promoted good to moderate nannofossil preservation. 3 and 4 . Sample 101-633A-14X-2, 80-81 cm. Lower Pliocene periplatform chalk. Although overlying the sample illustrated in $\mathbf{1}$ and 2, overgrowth and dissolution of nannofossil elements in this sample are significantly greater. This enhanced diagenesis resulted from the higher initial content of platform-derived material. 


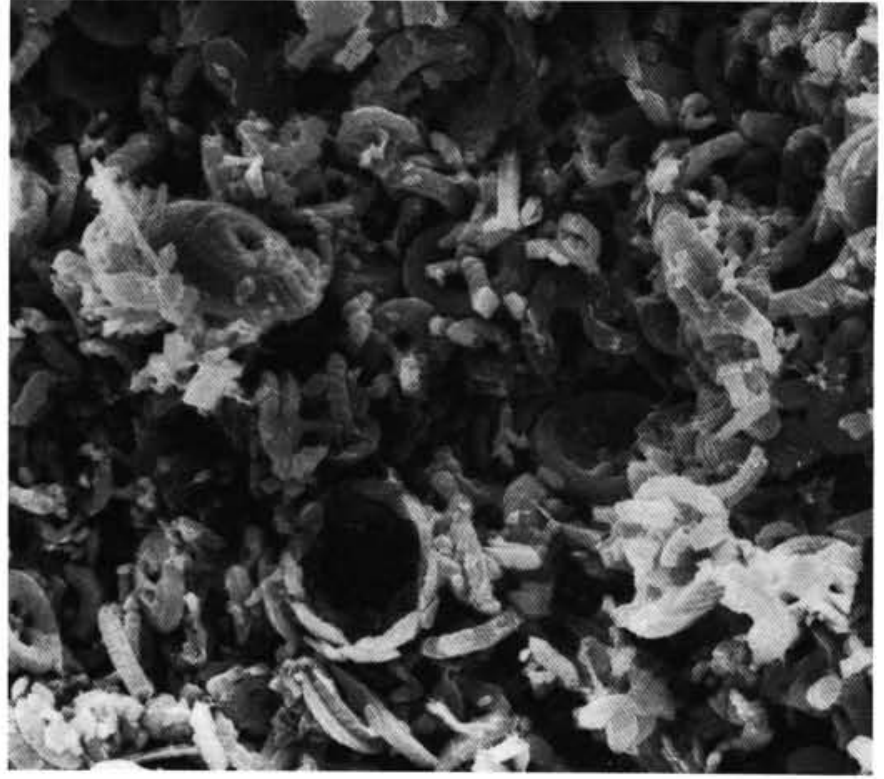

1

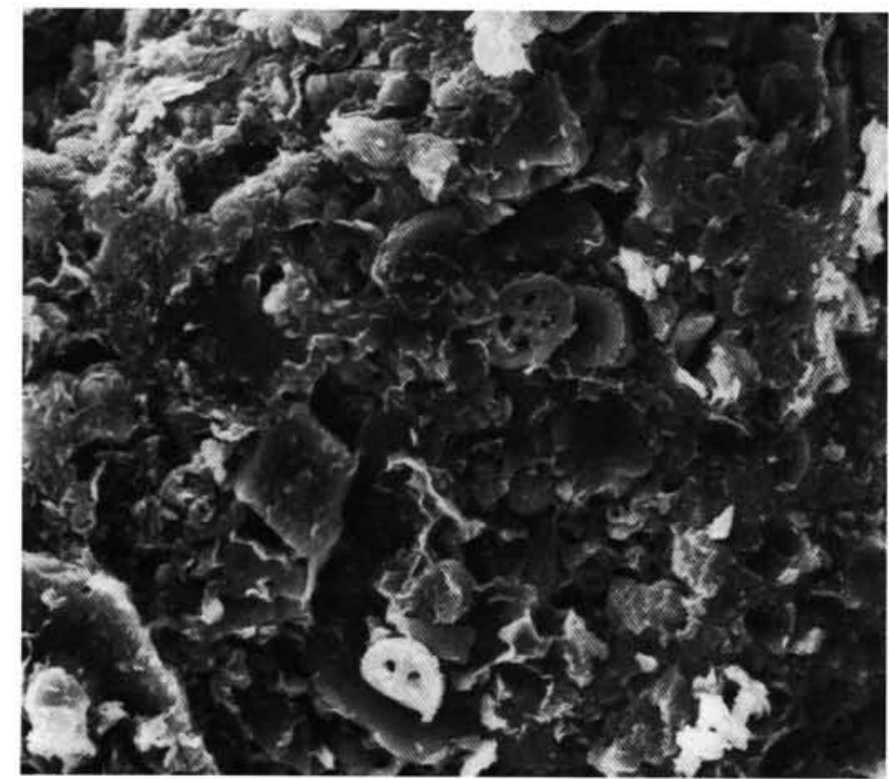

3

\section{$10 \mu \mathrm{m}$}
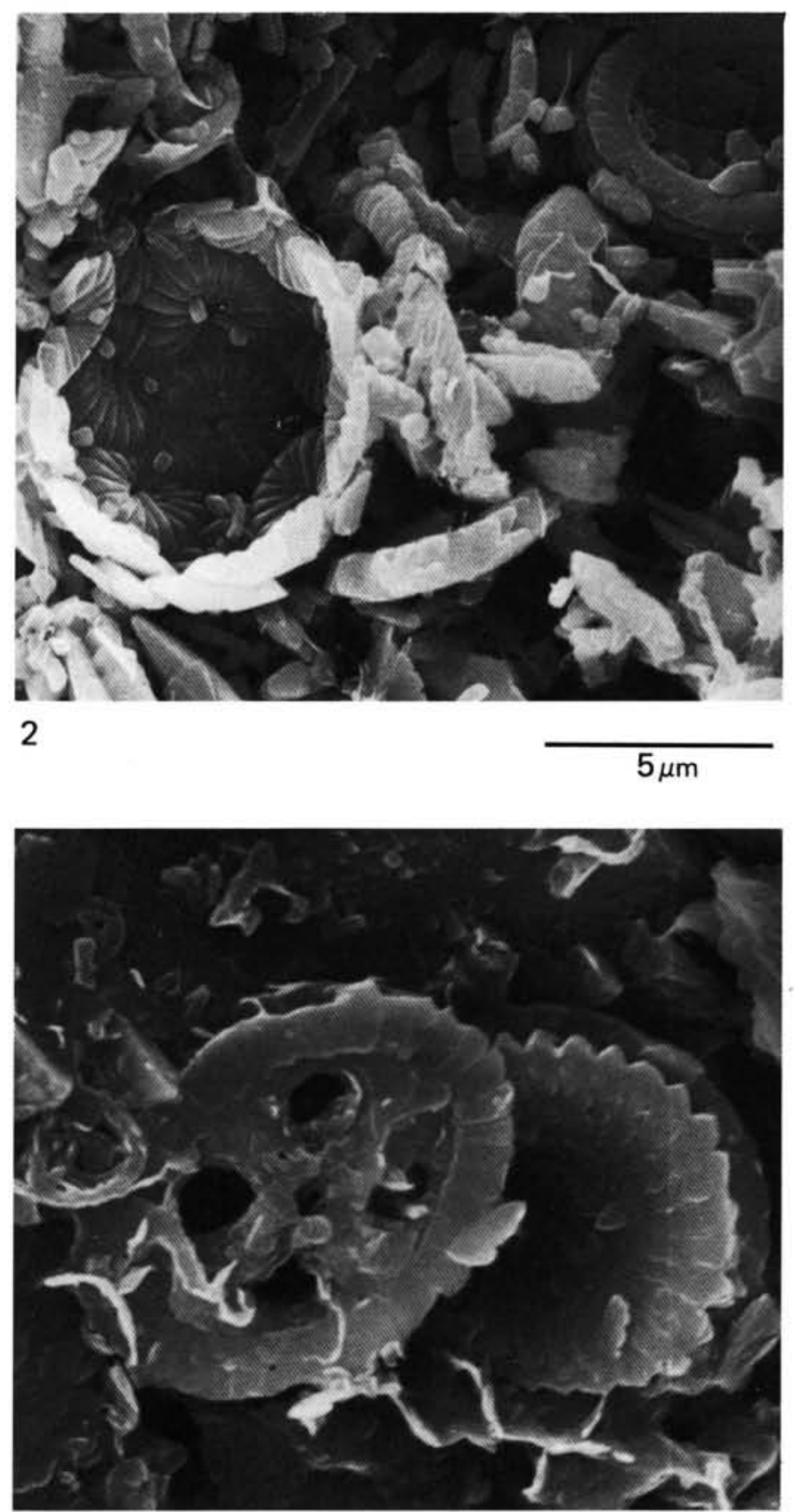

4

$\overline{1 \mu \mathrm{m}}$

Plate 3. 1. Upper Campanian chalk (Sample 101-627B-29X-1, 80-81 cm) illustrating abundance of nannofossils and lack of non-pelagic carbonate material. 2. Closeup of 1 illustrating relatively minor overgrowths on Bidiscus coccosphere (center left) and Broinsonia parca (upper right). 3. Middle Cenomanian hemipelagic marlstone (Sample 101-627B-38X-1, 80-81 cm) exhibiting relative dearth of nannofossil material in calcareous, clastic-rich matrix. 4. Closeup illustrating relatively strong syntaxial overgrowth of calcite elements in Axopodorhabdus albianus. 